SECTORAL CAPITAL FLOWS: COVARIATES, CO-MOVEMENTS, AND CONTROLS

Etienne Lepers

and

Rogelio Mercado, Jr.

The South East Asian Central Banks (SEACEN) Research and Training Centre (80416-M) Kuala Lumpur, Malaysia 


\section{SECTORAL CAPITAL FLOWS: COVARIATES, CO-MOVEMENTS, AND CONTROLS}

Etienne Lepers

and

Rogelio Mercado, Jr.

Version Date: 14 December 2020

First Draft: 01 June 2020

Disclaimer: This Working Paper should not be reported as representing the views of SEACEN or its member central banks/monetary authorities. The views expressed in this Working Paper are those of the author(s) and do not necessarily represent those of SEACEN or its member central banks/monetary authorities. 
Abstract $\quad$ v

1. Introduction $\quad 1$

2. Sectoral Capital Flows Data and Stylised Facts 4

2.1 Sectoral Capital Flows Dataset 4

2.2 Sectoral Flows Stylised Facts 8

3. Sectoral Capital Flows Covariates 8

3.1 Motivation $\quad 8$

3.2 Empirical Specification of Sectoral Flow Covariates 10

3.3 Sectoral Flow Covariates Results 10

4. Sectoral Flows Co-movements $r$

4.1 Theoretical and Empirical Motivation 11

4.2 Empirical Specification of Sectoral Flows Co-movement 12

4.3 Sectoral Flows Correlations 13

5. Sectoral Flows and Capital Controls 13

5.1 Empirical Motivation 13

5.2 Sectoral CFMs and Stylised Facts 15

5.3 Empirical Specification 16

5.4 Results, Sensitivity Tests, and Extensions 17

6. Concluding Remarks $r$

$\begin{array}{lr}\text { REFERENCES } & 20\end{array}$

\section{Figures and Tables}

Figure 1: Sectoral Resident Flows (US $\$$ billions) 24

Figure 2: Sectoral Non-Resident Flows (US\$ billions) 24

Figure 3a: Sectoral Resident Flows (US $\$$ billions), Advanced Economies 25

Figure 3b: Sectoral Non-Resident Flows (US\$ billions), Advanced Economies 25

Figure 4a: Sectoral Resident Flows (US $\$$ billions), Emerging Economies 26

Figure 4b: Sectoral Non-Resident Flows (US\$ billions), Emerging Economies 26

Figure 5a: Yearly Adjustments of Sectoral Controls on Sectoral

Non-Resident Flows $\quad 27$

Figure 5b: Yearly Adjustments of Sectoral Controls on Sectoral Resident Flows $\quad 27$

Figure 6a: Cumulative Adjustments of Sectoral Controls on Non-Resident Flows 28

Figure 6b: Cumulative Adjustments of Sectoral Controls on Resident Flows 28

Table 1: Summary Statistics: Dependent and Independent Variables 29

Table 2: Sectoral Flows Covariates - Baseline $\quad 30$

Table 3: Sectoral Flows Covariates - Extension Baseline

(Advanced Economies)

Table 4: Sectoral Flows Covariates - Extension Baseline

(Emerging Economies) 32

Table 5: Sectoral Flows Covariates - Extension Baseline

(Equity Flows)

Table 6: Sectoral Flows Covariates - Extension Baseline

(Debt Flows)

Table 7: Co-movement of Sectoral Flows - Conditional Correlations

Baseline (Conditional on Baseline Regressors and 
Country Fixed Effects)

Table 8: Number of Capital Control Adjustments, by Sector and Instrument

Table 9: Non-Resident Sectoral Flows on Non-Resident Sectoral Controls

(Summary of Estimates)

Appendix 1: Sectoral Flows Data Summary

Appendix 2: Country Classification $\quad 38$

Appendix 3: Data Definitions and Sources $\quad 39$

Appendix 4: Coding Capital Controls Dataset $\quad 41$ 


\title{
Sectoral Capital Flows: Covariates, Co-movements, and Controls
}

\author{
Etienne Lepers* and Rogelio Mercado, Jr.+
}

Version Date: 14 December 2020

First Draft: 01 June 2020

\begin{abstract}
This paper assembles a comprehensive sectoral capital flows dataset for 64 advanced and emerging economies from 2000-18, including direct, portfolio, and other investment to and from central banks (CB), general government (GG), banks (BKs), non-financial corporates (NFCs) and other financial corporates (OFCs) and a corresponding dataset on capital controls imposed on these sectors. Using these datasets, this paper illustrates the usefulness of a sectoral approach in assessing capital flow covariates, co-movements, and the effectiveness of capital controls. The findings underscore the sensitivity and cyclicality of OFC flows; and offer new evidence on the impact of sectoral controls on BKs, NFCs, and OFCs in lowering gross inflows to these sectors.
\end{abstract}

Keywords: sectoral capital flows, capital flows correlations, capital controls

JEL codes: F21, F38, F41, and G20

\footnotetext{
*Economist, Organisation for Economic Co-operation and Development (OECD), etienne.lepers@oecd.org +Economist, Asian Development Bank (ADB), rmercado@adb.org. The authors appreciate the comments and suggestions of Winfrid Blaschke, Maria Borga, Mangal Goswami, Bryan Hardy, Jong-Woo Kang, Cyn-Young Park, Ole Rummel, Cedric Tille, Frank Warnock, and participants of the Asian Development Bank RCI-POD webinar \#10. The views expressed in this paper are those of the authors and do not reflect the official views of the ADB, OECD or any of its member economies. An earlier version of this paper was released as SEACEN Working Paper 04/2020 on 15 June 2020.
} 


\section{Introduction}

Capital flows have been studied from various angles, such as determinants or covariates, cyclicality of capital flows, gross flow co-movements, and the impact of capital account openness.' Existing studies have generally focused on aggregate or specific types of flows, highlighting the importance of the composition of capital flows and differentiating between non-resident and resident gross flows in understanding capital flow dynamics. More recently, several papers considered capital flows along sectoral lines, demonstrating the usefulness of a sectoral perspective in understanding capital flow episodes and trends, as well as their drivers and consequences.

Work on sectoral flows has notably highlighted the central role of the banking sector in driving aggregate capital flow patterns. Indeed, the surge and sudden stop before and during the global financial crisis (GFC) of 2008-09 can largely be explained by banking sector flows (Milesi-Ferretti and Tille, 2011). The retrenchment of banking sector flows also largely explains the moderate levels of gross flows in post-GFC years (McCauley et al., 2019; McQuade and Schmitz, 2017). Empirical work also emphasized the procyclicality of the banking sector (Avdjiev et al. 2018; Hoggarth et al 2016; and Cerutti and Hong 2018), as well as its role in driving inflows and outflows co-movements (Avdjiev et al. 2018; Kumhof et al 2020).

Although recent studies have significantly extended our understanding of sectoral flow patterns, they only provide a partial account of sectoral flows by focusing on specific types of flows to and from broader sectoral groupings, focusing mainly on debt flows to corporates, sovereigns, and banks (Avdjiev et al., 2018; and Cerutti and Hong, 2018) ${ }^{2}$. The objective of the present paper is to provide a more complete sectoral assessment of gross capital flows, by including both equity and debt type investments, and, by providing a finer sectoral breakdown. We demonstrate that such finer and more complete perspective is necessary to understand more recent capital flow behaviour in advanced and emerging countries.

First, this paper seeks to disentangle the specificities of non-bank financial institutions cross-border behaviour (typically lumped in existing studies together with nonfinancial corporates) relative to banks and non-financial corporates. The post-GFC period has indeed seen a dramatic increase in the role played by non-bank financial institutions (or OFCs) in the global financial system (Patalano and Roulet, 2020). In the case of the U.S., the assets of non-bank financial institutions have increased from $44 \%$ of GDP in 1980 to $155 \%$ in 2016 , with the ratio of deposit bank assets to non-bank assets decreasing from $142 \%$ to $40 \%$ in the same period. This paper provides novel evidence that in advanced economies, OFC flows have become the dominant driver of resident flows as $\mathrm{BK}$ flows retreated.

\footnotetext{
1 On covariates using global (push) and domestic (pull) factors, see Calderon and Kubota (Calderón and Kubota, 2013), Calvo et al. (1993), Cavallo and Frankel (2008), Chuhan et al. (1998), Forbes and Warnock (2012), Fratzscher (2012), Ghosh et al. (2014), Li et al. (2018), Mercado and Park (2011), Mercado (2018), Puy (2016), and Reinhart and Reinhart (2008). On cyclicality of capital flows, refer to Kaminsky et al (2004). On correlations, see Avdjiev et al. (2018), Alfaro et al. (2014), Broner et al. (2013), and Davis and van Wincoop (2018). On capital controls, see Ahmed and Zlate (2014), Chamon and Garcia (2016), Forbes et al (2015), Lepers and Mehigan (2019), and Magud and Reinhart (2006).

${ }^{2}$ Avdjiev et al. (2018) focused on debt flows to and from banks, corporates, and sovereigns at a quarterly frequency from 1996 to 2014 for 81 advanced and emerging economies. Cerutti and Hong (2018) considered portfolio and other investment inflows to corporates, banks, and sovereigns for 43 advanced and emerging economies. Hoggarth et al (2016) focuses on debt inflows from bank or non-bank creditors.
} 
Implications of this rise of OFCs, notably in terms of financial stability, are yet to be understood but the recent COVID-19 crisis already provided a dramatic example. Unlike the GFC, the sudden stop experienced by many countries during the recent COVID-19 crisis appeared to be mainly driven by investment funds, while banking sector flows appeared resilient and countercyclical (Lane, 2020). ${ }^{3}$ The behaviour, drivers and consequences of OFC capital flows may be different than of NFCs and BKs flows. For example, NFCs undertake greater controlling stake and long-term corporate investments, while OFCs (pension, insurance, money market, and investment funds) are financial actors with radically different investment objectives and horizons compared to NFCs. Similarly, BKs have different features than OFCs.

Second, the paper differentiates between flows to and from central bank/monetary authority (CB) and those general government (GG), which are usually analysed indifferently as "public sector" flows. Such distinction is meaningful as GG sector is usually net borrower, while CB is a net investor through their foreign reserves. We show that $C B$ outflows have overpassed all other sectoral flows in the pre-crisis period in EMEs, reflecting the reserve accumulation of EM central banks in post-Asian financial crisis. On the other hand, we show that inflows to GG have been particularly important at times, outstripping other sector inflows from 2011 to 2015, reflecting the relatively higher investment in government bonds post-GFC.

Third, this paper captures sectoral flows across almost all functional categories of the Financial Account Balance of the BoP. ${ }^{4}$ Capturing equity (FDI and portfolio equity) on top of debt flows is particularly important in the case of EMEs. For instance, almost half of non-resident capital flows to emerging Asia economies are in the form of foreign direct investments and such flows are mainly related to non-financial corporates. Ignoring equity flows may provide an incomplete assessment of sectoral flows to EMEs. Furthermore, including equity flows allows us to assess whether equity flows to different sectors behave differently than sectoral debt flows.

Our final sectoral flow dataset, compiled from different sources, includes 28 advanced economies (AEs) and 36 emerging economies (EMEs) from 2000-18. It covers all types of flows (equity and debt investments) with finer sectors grouping (including CB, GG, BKs, NFCs, and OFCs). In addition, we also constructed the first sectoral capital controls dataset extending Lepers and Mehigan (2019) capital controls dataset across our five sectors. Our capital controls dataset provides a unique instrument and sectoral breakdown and includes all tightening and easing actions to capture adjustments in controls (and not simply the absence or presence of restrictions). This addresses several issues usually plaguing capital controls datasets, namely the lack of differentiation across types of controls, no consideration of the intensity of the controls, and a small number of capital control "actions".

Armed with these two datasets, the objective of this paper is to leverage on our finer sectoral groupings and more comprehensive BoP coverage to understand more precisely what is driving the sector-specific capital flow patterns above mentioned and their implications. First, we start by looking at differences in the drivers of different sectoral resident and non-resident flows, looking both at their relative responsiveness

\footnotetext{
3 Throughout this paper, we refer to non-bank financial institutions as other financial corporates (OFCs). 4 We exclude sectoral breakdown of resident and non-resident financial derivatives as they are mostly reported in net basis.
} 
to global financial conditions and to domestic business cycles. Next, as several covariates drive non-resident and resident sectoral flows in the same direction, we consider the co-movement of non-resident and resident sectoral flows to assess whether positive co-movement reinforces global imbalances. We seek to determine which sector drives the strong positive correlation between resident and non-resident flows. Lastly, we augment our model with sectoral capital controls to examine whether adjustments in capital controls applied to specific sectors amplify or diminish these sectoral flow movements and sensitivities.

On sectoral flows covariates, our finer breakdown of private and public sectors reveals new sectoral heterogeneities overlooked by previous work. Regarding domestic conditions, while inflows to BK, NFC, and OFC are all positively associated with domestic GDP growth, we find that an increase in domestic GDP is associated with an increase in domestic BKs investment abroad but a decrease in domestic OFCs investment abroad. OFCs thus appear to reduce their foreign investments when the domestic economy expands consistent with theoretical priors. We also confirm the countercyclical role of government (GG) inflows vis-a-vis the domestic business cycle. Regarding the responsiveness to global conditions, the results show that BKs, NFCs, and OFCs receive more inflows and increase investment abroad during global expansions. Risk aversion (VIX) however does not appear to be a significant driver of flows to and from NFCs.

These results have in turn implications for resident and non-resident flows comovements, which we considered next. We find that same sector inflows and outflows account for a large part of the observed positive correlation between sectoral flows. But looking into inter-sectoral patterns, the results underscore the importance of OFC sectoral flows in explaining the observed positive correlation between gross flows across sectors, as it is the only sector significantly correlated with most sector flows.

Finally, we provide the first analysis assessing the effectiveness of capital controls on sectoral flows by classifying capital controls along sectoral lines. We provide some evidence that the introduction or tightening sector-specific controls may be effective in lowering the volume of corresponding sector flows. We indeed find some evidence that tighter capital controls on non-resident flows to BK, NFC and OFC are associated significantly with lower flows to these sectors. This contrasts with existing research, which generally finds no volume effect using aggregate or instrument-based capital control datasets.

This findings make several contributions to the empirical literature on capital flows. Most notably, by isolating OFC flows from BK and NFC flows, this paper extends existing literature by highlighting the strong responsiveness and cyclicality of non-bank financial institutions (OFCs), which are in recent years the leading capital flows in advanced economies. Unlike other private sector flows, foreign investment by resident OFCs is countercyclical with regards to domestic output growth. Since the results are mainly attributed to advanced economies, this implies that a robust expansion in advanced economies might dampen OFC outflows. The OFC sector significantly also contributes to the observed positive correlation between sectoral gross inflows and outflows.

These results have implications for theoretical work on the observed positive correlation between inflows and outflows must consider that this correlation is mainly 
driven by same sector inflows and outflows, in line with Davis and van Wincoop (2018) and Davis (2015). Recent work by Kumhof et al (2020) argues that gross inflows and outflows are necessarily correlated as an automatic result of accounting rules as all financial transactions are settled through opposite flows in the banking system. While this can explain the high correlation between BK inflows and outflows, the significant positive correlations of NFC and OFC flows remains unexplained and further studies are needed.

We also contribute to ongoing work on refining capital flows statistics. Our sectoral dataset is the first to decompose direct investment flows, portfolio, and banking flows into a common sectoral mapping. The inclusion of direct investment (DI) provides a more accurate assessment on the behaviour of NFC sectoral flows which drive a large part of FDI and a more accurate picture of sectoral flows in EMEs for which FDI is often the most important type of flow. Applying a common data compilation and reporting standard for all sectors of the financial account balance, including direct investment, will improve our understanding of capital flow dynamics. Going forward, sectoral decompositions of direct investment flows as part of BoP sectoral reporting would provide a major way forward and ongoing efforts in this direction at the IMF and OECD are thus particularly welcome. In addition, this paper emphasized better statistics on the non-bank financial sector will prove crucial.

In terms of policy implications, this paper highlights the potential financial stability implications from the procyclicality of private sector flows, and specifically OFC flows to global financial conditions. As this paper shows, the substantial increase in OFC investment abroad in recent years coincided with the willingness of domestic regulators to permit greater portfolio diversification abroad which decrease domestic idiosyncratic risk but prove vulnerable to global shocks of the scale of the one experienced in the recent COVID-19 crisis (De Crescenzio and Lepers 2020). In addition, the intra-sectoral procyclicality of resident and non-resident flows in all private sectors adds another argument for a countercyclical approach to prudential policy (Araujo et al., 2017; Lane and McQuade, 2014). Finally, our results on the impact of sectoral controls on corresponding sectoral flows highlights the usefulness of sectoral approach on issues related to capital flow management. This also points to the importance of the current debates on macroprudential policy beyond banking (e.g. ESRB 2016).

This paper proceeds as follows. In Section 2, we discuss our sectoral capital flows dataset and provide stylised facts. Readers interested in sectoral flows covariates may proceed to Section 3. Those interested in sectoral flows co-movements may proceed reading Section 4; while those interested on sectoral controls may proceed to Section 5. Section 6 provides concluding remarks.

\section{Sectoral Capital Flows Data and Stylised Facts}

\subsection{The construction of a new Sectoral Capital Flows Dataset}

\section{The sectoral breakdown in the IMF Balance of Payment Statistics}

The primary data source of our sectoral capital flows dataset is the IMF's Balance of Payments Statistics (BoP). The BoP statistics report a sectoral breakdown for portfolio 
debt; portfolio equity; currency and deposits; loans; trade credits and advances; insurance and pension funds; and, other receipts and payables for resident (assets) and non-resident (liabilities) flows. The reported sectors include central banks/monetary authorities (CB), general government (GG), banks (BKs), nonfinancial corporations (NFCs), and other financial corporations (OFCs). ${ }^{5}$ Reported sectoral breakdowns are based on the residency principle of cross-border financial transactions. For financial account assets, the sectoral classification refers to the resident or source sector undertaking a net acquisition of foreign assets. For financial account liabilities, sectoral classification pertains to the resident investee or recipient sectors of non-resident flows, which represent a net incurrence of liabilities to nonresidents.

As the IMF's BoP Statistics reports the sectoral breakdown for portfolio and other investment flows, the largest share of our sectoral breakdown are actual flows data. However, some economies do not report a detailed breakdown of Other Sector flows into NFC and OFC flows for some or all years. In addition, there are years when some countries do not report specific sectoral flows for CB, GG, and/or BKs. In these cases, we attempt to fill in missing values from other data sources or to proxy the value based on weights from stock data.

\section{Additional data filling steps}

We start with a few straightforward data filling steps. For cases when data for either CB, GG, BKs, or Other Sector is unreported, we take the difference between total flows and the three reported sectors to come up with the value for the missing sector, similar to Avdjiev et al. (2018). For filling-in the breakdown of Other Sector flows into NFC and OFC sectors for years without a breakdown, we use reported classification for years with available breakdown to determine whether the unclassified values fall into either NFC or OFC. For instance, if a country classifies Other Sector flows into NFC for 20132018 but reports Other Sector flows for 2000-12, then the unclassified values from 20002012 will be classified under NFC flows. The same method is applied even if there are reported OFC values (whether zero or non-zero) for later years, say from 2015-18, as the values from 2013-14 must be attributed to NFCs. For trade credit and advances, unclassified reported Other Sector flows data are classified under NFCs based on classification of most reporting economies. For insurance and pension flows, unclassified reported Other Sector flows data are classified under OFCs based on classification of most reporting economies.

\section{Computing missing values from average sectoral weights of missing sectors}

Next, on data computation, for cases when values for two or more sectors are missing, data are calculated by multiplying the reported total flows by the average sectoral weight(s) of the missing sector(s). Similarly, for years with missing Other Sector breakdown between NFC and OFC sectors, values for either NFCs or OFCs are derived

\footnotetext{
5 Based on Balance of Payments Manual 6, banks (BKs) are deposit-taking corporations except the central bank. Non-financial corporations (NFCs) include non-financial corporations, households, and non-profit institutions. Other financial corporations (OFCs) include money market funds, investment funds, other financial intermediaries, financial auxiliaries, captive financial institutions and money lenders, insurance corporations, and pension funds. For earlier years, BoP statistics group NFC and OFC flows as Other Sector flows. In contrast to Avdjiev et al. (2018), we used reported data for NFCs and OFCs and estimated missing values for these two sectors.
} 
by multiplying the reported Other Sector flows by the average sectoral weight for the missing sector. Values for the remaining missing sector are then computed as the difference between the value for reported Other Sector flows and the computed value for NFC or OFC flows. In both cases, the average sectoral weights are derived as the share of reported sectoral holding to total holdings.

For portfolio flows, the weights are primarily derived from the IMF's International Investment Position (IIP), then the IMF's Coordinated Portfolio Investment Survey (CPIS) if IIP data is unavailable, in that order. For other investment flows, weights were taken from IIP and then Bank for International Settlements Locational Banking Statistics (BIS LBS). The use of IIP sectoral breakdown is our preferred data source because it is the stock equivalent of the Financial Account Balance of the BoP Statistics. Among the sources, LBS is used last as the data pertains to banking sector counterparty data only ${ }^{6}$.

Among the different types of capital flows, sectoral breakdowns of direct investment and foreign direct investment are most difficult to compute. Unfortunately, the BoP Statistics does not provide a sectoral breakdown for direct investment flows. However, excluding direct investments would provide an incomplete picture of total gross sectoral flows. Instead of assuming that direct investment flows are all NFC flows as is usually done, we seek to compute a more precise sectoral breakdown, as other sectors like OFCs and BKs also undertake direct investments. Consequently, we classify sectoral direct investment flows into BKs, NFCs, and OFCs. GG and CB are not expected to undertake direct investments.

The sectoral values for direct investment resident and non-resident flows are calculated based on derived average weights of BK and OFC sectors to total direct investment of an economy. Direct investment weights for BKs and OFCs are derived based on reported stock or flow values on direct investment abroad (assets) and foreign direct investment (liabilities) by economic activity.

For some economies, detailed DI breakdown between BKs and OFCs are reported, in which case the weights for both BKs and OFCs are computed relative to total direct investment abroad and foreign direct investment; while the weights for NFCs are derived as the residual value of shares such that the total of NFC, BK, and OFC shares must sum to one (1). Consequently, NFC sectoral weights refer to the share of all economic activity excluding financial services to total direct investment abroad or foreign direct investment. Data on direct investment abroad and foreign direct investment by economic industry are sourced from the OECD Foreign Direct Investment Database (FDI positions) and national sources accessed through the CEIC. ${ }^{7}$ For the few remaining economies without industry breakdown on financial services for direct investment abroad and foreign direct investment, sectoral weights for BKs and OFCs are computed as the share of financial services to total direct investments multiplied by the respective shares of BKs and OFCs assets to total domestic financial system assets. These shares are derived using their respective asset

\footnotetext{
6 See Luna and Hardy (2019) for a discussion on BIS LBS sectoral data.

7 Such data sources classify direct investment by economic activity according to the ISIC classification (International Standard Industrial Classification of All Economic Activities). We map this classification into the BoP sectoral breakdown that we have for portfolio and other flows: namely, banking sector (BK) are activities engaged in monetary intermediation, while non-bank financial corporate (OFC) are those for insurance and pension funds, trust funds, and holding companies.
} 
holdings to total domestic financial system assets as reported by the IMF's Financial System Stability Assessment country reports for available years.

Average sectoral weights are used instead of annual (time-varying) weights to smoothen sharp fluctuations in weights (especially for weights based on flows data such as the case for some of our direct investment flows). .8 In addition, the computed sectoral flows, based on average weights, are interpreted as "expected" sectoral flows, which can be viewed as "how much a sector is expected to invest or borrow from abroad over time". The practical choice of using average weights is also driven by data constraints. For instance, sectoral holdings data from BIS LBS, which is used for other investment flows, are only available for 2013-2018. For instance, average weights from 2013-18 were used to classify values for NFCs and OFCs for 2000-12. OECD sectoral FDI positions are also patchy for many countries in many of the years. Although the composition of sectoral financial holdings changes over time, we believe that average weights provide the best option in the context of scarce and uneven annual sectoral data. Consequently, our average weights provide the best available estimate of which of the sectors are "expected" to receive more and less flows. 9

To complete the dataset, we classify official reserve assets as belonging to $\mathrm{CB}$ and other equity flows are assumed to fall under $G G$ as it includes transactions pertaining to quasi-corporations and international institutions. Data on financial derivatives are mostly reported in net asset basis, hence they are excluded from the dataset. All reported zero values are included in the dataset. But for filled-in and computed sectoral flows, missing values are not left blank, i.e., not replaced by zero values.

\section{Finalizing our sectoral capital flow dataset}

After compiling sectoral flows for each financial account component, data are then added by sector, yielding total sectoral capital flows, which includes all types of investments. Our final sectoral capital flows dataset runs from 2000 to 2018 for over 41 economies for resident sectoral flows and 64 economies for non-resident sectoral flows. The difference between the number of economies for resident and non-resident flows is due to fact that some economies do not have reported breakdowns of direct investment abroad by economic activity. Consequently, these economies are excluded from the sample, yielding only 41 economies for resident sectoral flows.

Our final sectoral capital flows dataset comprises $73 \%$ of reported values, $7 \%$ of filledin values, and $20 \%$ of computed (expected) values across five sectors and different types of investment flows. 10 Sectoral direct investment flows data account for the largest share of computed values, as such breakdown is not reported in IMF BoP statistics.

\footnotetext{
8 We average sectoral weights from all available annual data from 2000-18.

9 We conduct sensitivity tests by dropping 8 economies whose sectoral flows are mostly derived values. Our baseline results hold. Refer to Section 3.3.

10 See Appendix 1 for data computation summary; and refer to metadata for review.
} 


\subsection{Sectoral Flows Stylised Facts}

Figures 1 and 2 show sectoral resident and non-resident flows, respectively, from our dataset. Both figures document the dramatic rise and fall of banking sector (BK) flows around the global financial crisis of 2008-09. Moreover, the figures show that the banking sector has not fully recovered in the years that followed, consistent with work by McCauley et al. (2019) and McQuade and Schmitz (2017). This reflects in part the global retrenchment of banking activities post-GFC.

Figure 1 reveals the substantial increase of resident OFC flows relative to other flows. In fact, for 2017-18, resident OFC flows dominate resident flows, outpacing NFCs and consistent with the substantial reduction in outward investment restrictions for OFCs, notably in advanced economies. ${ }^{11}$ On the inflow side, flows to NFCs remain the largest sectoral inflows since 2008.

These global trends closely follow those of advanced economies, shown in Figures $3 a$ and $3 \mathrm{~b}$, which is not surprising given the volume of AEs cross-border transactions. For emerging economies, resident flows are dominated by BK, NFC, and CB sectors in recent years (Figure 4a). ${ }^{12}$ The pre-GFC rise in CB outflows reflect the well-known accumulation of reserves by EM central banks in the first half of the 2000's. For EM nonresident flows (Figure 4b), inflows to NFCs are the largest, in line with Avdjiev et al. (2014), followed by non-resident BK flows. Inflows to GG have also risen, reflecting the increase shift post-GFC to investment in government bonds.

These stylised facts based on our sectoral capital flows data confirm the general patterns of gross capital flows highlighted in past research (Milesi-Ferretti and Tille 2011; McQuade and Schmitz 2017). BK sector flows account for the huge rise of gross flows pre-GFC; their subsequent drop during the GFC; and for the tepid flows post-GFC. NFC flows have been rising, especially in EMEs while inflows to GG have also risen. BK sector flows have traditionally been the most volatile, particularly in the pre- and crisis years. What is new in our stylised facts is that these sectoral flows now include all types of capital flows. More importantly, we document and quantify the growing importance of resident OFC sector flows, especially in advanced economies.

\section{Sectoral Capital Flows Covariates}

\subsection{Motivation}

Capital flows are driven by push and pull factors. Existing studies on capital flows have tested the relevance of these two factors in determining the magnitude and volatilities of capital inflows and their components; the occurrence of sudden stops and surges; the size of capital flows during extreme episodes, and the proportion of variance attributed to each of these factors. ${ }^{13}$ The use of the push and pull framework

\footnotetext{
11 See Appendix 2 for country list and classification.

12 Resident sectoral flows for emerging economies exclude Brazil, China, Indonesia, and Russia, which are large emerging economies, due to data unavailability for sectoral direct investment flows.

13 Refer to Ahmed and Zlate (2014), Byrne and Fiess (2016), Fratzscher (2012), Mercado and Park (2011), Milesi-Ferretti and Tille (2011), and Wang (2018) on the size or magnitude of capital flows; Calderon and Kubota (2013), Cavallo and Frankel (2008), Forbes and Warnock (2012), and Reinhart and Reinhart (2009) on the occurrence of sudden stops and/or surges; Ghosh et al. (2014), Li et al. (2018) and Mercado (2018) on the occurrence of surges and associated magnitude of capital flows; Calvo et al. (1993) on global 
as an analytical tool in understanding the covariates of capital flows has important policy implications. If push factors are more relevant, policymakers have little control over capital flows and hence, they must rely on domestic financial resilience to counter the adverse consequences of huge and volatile capital inflows. On the other hand, if pull factors are more relevant, policy makers have more levers to influence the size, composition, and volatility of cross-border financial inflows.

Empirical studies provide strong evidence for the relevance of push or global factors such as global or advanced economy output growth, global interest rates, global commodity price levels, global liquidity and global investor risk aversion. ${ }^{14}$ More recent papers propose that global factors that drive capital flows relate to financial conditions in advanced economies. Financial conditions in advanced economies impact risk aversion and uncertainty, leading to co-movements in capital flows and asset prices, constituting a global financial cycle (Rey, 2016, 2013). Yet most studies also highlight the importance of pull or domestic factors. Strong output growth, lower macroeconomic risks, trade and financial openness, quality of governance, and financial depth of receiving economies are associated with larger capital inflows. ${ }^{15}$ Of importance is the significance of domestic growth on gross flows as it suggest cyclicality of capital flows in relation to domestic output. If the domestic growth and capital inflows are pro-cyclical, then this may exacerbate financial fragilities and may lead to financial instability. For instance, strong domestic growth may lead to larger external borrowings of BK and NFC sectors. On the other hand, gross flows and domestic growth may be countercyclical as growth slows, since economic sectors may borrow more abroad, leading to large gross inflows.

This section aims to assess the significance of capital flow covariates, with emphasis on global financial conditions and domestic output growth from a sectoral angle. Avdjiev et al. (2018) found evidence that adverse change in global financial conditions lead to decline in inflows to banks and corporates, while domestic banks and corporates invest less abroad, decreasing their outflows. We undertake a similar empirical analysis but extending the results from debt flows to total sectoral flows, as well as providing a finer sectoral classification that includes OFCs, which may react differently than NFCs. ${ }^{16}$ Specifically, this section asks: 1) are sectoral flows responsive to global financial conditions; and, 2) are sectoral flows pro-cyclical, counter-cyclical or acyclical to domestic output growth? Considering the responsiveness of sectoral resident and non-resident flows to a common set of push and pull covariates allows

\footnotetext{
factor principal component analysis; and Cerutti et al. (2019), Chuhan et al. (1998), Puy (2016), Sarno et al. (2016), and Shirota (2015) on variance decompositions of global and domestic factors.

14 Higher global growth is significantly correlated with higher inflows in EMs (Li et al., 2018), while higher global interest rate is strongly associated with lower capital inflows to emerging economies (Byrne and Fiess, 2016; Giordani et al., 2017; Ghosh et al., 2014; Li et al., 2018; and Mercado, 2018). Higher commodity prices tend to increase capital inflows to emerging/developing economies (Byrne and Fiess, 2016; Mercado, 2018; Reinhart and Reinhart, 2008). Higher global risk aversion leads to reversals of inflows, more so during periods of financial stress (Ahmed and Zlate, 2014; Fratzscher, 2012; Ghosh et al., 2014; and Giordani et al., 2017).

15 Higher domestic growth signifies higher potential profits (Giordani et al., 2017; Mercado and Park, 2011 ). Lower or stable inflation signals macroeconomic policy stability, while higher domestic interest rate, relative to world or foreign interest rate, relates to higher expected returns (Li et al., 2018). Byrne and Fiess (2016), Ghosh et al. (2014), Mercado and Park (2011) and Mercado (2018) also affirm the importance of trade and financial openness, governance, and financial depth.

16 In most sectoral flow work, OFC and NFC sectors are grouped as "corporate sector".
} 
us to highlight commonalities and differences in sensitivities of $C B, G G, B K, N F C$, and OFC sectors.

\subsection{Empirical Specification of Sectoral Flow Covariates}

To address the questions, we consider a common set of covariates and assess their significance on sectoral capital flows. Specifically, we estimate:

$$
C F_{i, j . t}=\alpha+X_{t}^{G} \beta^{\prime}+X_{i, t-1}^{D} \gamma^{\prime}+\varepsilon_{i, j, t}
$$

(Equation 1)

where CF refers to resident and non-resident sectoral flows of country $i$, sector $j$, and time tin percent of nominal GDP. X pertains to row vector of contemporaneous global (G) and domestic (D) covariates. For global factors, we include factors that capture global financial and economic cycles driving capital flows, namely global growth, global liquidity, global risk aversion, and global commodity price. ${ }^{17}$ They are included in the empirical specification in their contemporaneous values as capital flows respond instantaneously with global covariates, all the more so as we are using annual values (Ghosh et al., 2014; Mercado, 2018). For domestic factors, we focus on domestic GDP growth in our baseline regression as it captures domestic business cycles, but also test structural domestic factors in our sensitivity tests. Domestic GDP growth is lagged by one year to limit endogeneity. Equation 1 is estimated with country-fixed effects to account for unobserved heterogeneities, and robust standard errors clustered at country level are used. The estimation involves annual values from 2000-18. Table 1 presents the summary statistics of resident and non-resident sectoral flows in percent of GDP and global and domestic covariates.

\subsection{Sectoral Flow Covariates Results}

Table 3 presents the covariates of non-resident and resident sectoral flows. Regarding domestic conditions, non-resident BK, NFC, and OFC flows are positively associated with domestic GDP growth. For instance, a $1 \%$ increase in domestic GDP growth leads to $0.3 \%$ of GDP additional inflows to banks. In contrast, resident BK and NFC sector flows are procyclical, while resident OFC flows are countercyclical to domestic business cycles. The latter result is consistent with the theory given that stronger domestic growth should encourage investment, pension, and insurance funds to invest more in the domestic market. Non-resident GG flows are negatively correlated with domestic output growth, while $C B$ resident and non-resident flows are nonresponsive to it. We thus add to previous findings on public sector flows lumping CB and GG into one category (e.g. Alfaro et al (2014).

Regarding the responsiveness to global conditions, we find BK, NFC, and OFC sectors generally receive more inflows and increase investment abroad during global expansions. Higher global output growth and liquidity are positively associated with higher BK, NFC, and OFC sector inflows and outflows. In contrast, higher global risk aversion reduces non-resident BK sector flows, and resident OFC sector flows. It appears that non-resident and resident NFC flows are nonresponsive to global risk aversion. In addition, higher global commodity prices lead to lower flows to and from

17 Global GDP growth and domestic GDP growth are year-on-year change in percentage terms. Global liquidity, global risk aversion, and global commodity price are indices. Refer to Appendix 3 for data definitions and sources. 
the financial sector as a whole (BK and OFC), while leading to higher GG inflows. NFC inflows and outflows appear non-responsive to changes in global commodity prices.

These findings hold in several sensitivity tests, including 1) using pooled OLS estimation; 2) adding lagged sectoral flows in the regression specification; 3) removing 8 economies whose sectoral flows data have significantly more computed values to check whether the baseline findings are sensitive to our computation methodology; 4) adding structural domestic factors; 5) winsorising nonresident and resident sectoral flows at the top and bottom 10\%; and 6) replacing VIX with risk premia. ${ }^{18}$

Aside from the baseline results and sensitivity tests, several extensions were conducted. First, splitting the sample into advanced and emerging economies reveals the baseline results are driven by advanced economies (Table 3). For emerging economies, fewer covariates are significant (Table 4). However, the negative association between OFC outflows and domestic GDP growth and the countercyclical role of inflows to governments holds. Second, we split the sample into equity and debt flows, where equity flows include direct and portfolio equity, and debt flows are portfolio debt and loans. For equity flows, higher global liquidity is positively associated with higher non-resident and resident BK, NFC, and OFC sector flows (Table 5). For debt flows, non-resident and resident BK, NFC, and OFC sector flows are responsive to global output growth and liquidity conditions (Table 6). For nonresident debt flows, there is a clear distinction between private (BK, NFC, and OFC) and public (CB and GG) sector cyclicality with domestic GDP growth.

In summary, this section illustrates non-resident and resident sector flow heterogeneities in responses to global and domestic covariates. We find BK, NFC, and OFC sectoral flows are responsive to measures of global business and financial cycles, albeit to different extent. Regarding the procyclicality to the domestic business cycle, while inflows to BK, NFC, and OFC increase with domestic GDP growth, inflows to GG decrease as government debt issuance decreases. In addition, resident OFC flows decline when the domestic economy expands, unlike BK and NFC sectors which invest more abroad when the domestic economy grows.

\section{Sectoral Flows Co-movements}

\subsection{Theoretical and Empirical Motivation}

Results in the previous section suggest potential co-movements between sectoral inflows and outflows, as we show that some covariates are driving non-resident and resident flows in the same direction. This section seeks to formally analyse comovements in sectoral flows. Real business cycle models predict that higher productivity raises expected returns, leading to higher non-resident inflows but lower resident outflows. Under the same framework, higher perceived riskiness of domestic asset returns leads to a decline in non-resident inflows but an increase in gross outflows. Hence, resident and non-resident gross capital flows are expected to be negatively correlated. But existing studies show an increasingly positive correlation between resident and non-resident flows (Broner et al., 2013). This raises a puzzle to

18 The results for these sensitivity tests are presented in Tables S1 to S6 in the supplementary material. 
which more recent theoretical and empirical work have tried to provide answers. ${ }^{19}$ The positive correlation between gross inflows and outflows may raise concerns as it can reinforce global imbalances, especially if they are attributed to financial frictions and asymmetries between economies (Broner et al., 2013; Tille and van Wincoop, 2010). ${ }^{20}$

While most studies on the correlation between gross inflows and gross outflows focus on aggregate flows data, several recent papers have analysed these correlations through a sectoral lens. Davis and van Wincoop (2018) suggest that when capital inflows lead to an accumulation of official reserves, this may be combined with official reserve outflows, thereby reinforcing a positive correlation, especially for emerging economies. Davis (2015) proposes that the positive correlation may be driven by bank liquidity management where banks reduce their outward investment to manage liquidity shortfalls when faced with lower non-resident inflows. Using sectoral debt flow data, Avdjiev et al. (2018) find that, while a positive correlation is seen for all crosssector combinations, the size of the correlation for banking sector flows is by far the most important, particularly in advanced economies. On the conceptual side, recent work by Kumhof et al (2020) argues that gross inflows and outflows are necessarily correlated from an accounting perspective, as all financial transactions are settled through opposite flows in the banking system, potentially explaining the centrality of banks found in Avdjiev et al. (2018).

This section contributes to the literature on correlations or co-movements between resident and non-resident total sectoral flows. Specifically, it asks: which resident and non-resident total sectoral flows exhibit positive correlation? Again, our aim is to deepen existing evidence our finer sectoral classification and by covering total capital flows.

\subsection{Empirical Specification of Sectoral Flows Co-movement}

To address the question in this section, we consider sectoral correlations between resident and non-resident total sectoral flows. We estimate the contemporaneous conditional correlations based on the following equation:

$$
C F_{i, j . t}=\alpha+X_{t}^{G} \beta^{\prime}+X_{i, t-1}^{D} \gamma^{\prime}+S C F_{i, j, t} \delta^{\prime}+\varepsilon_{i, j, t}
$$

where CF refers to sectoral flows of country $i$, sector $j$, and time t in percent of nominal GDP. X pertains to the row vector of contemporaneous global (G) and domestic (D) covariates as discussed in Section 3. SCF is the row vector of other sectoral flows of country i at time t. We regress resident (non-resident) sectoral flows on non-resident (resident) sectoral flows. If the estimated coefficients are positive and significant, then we confirm which sectors may explain positive correlations between gross nonresident and resident flows.

\footnotetext{
19 Broner et al. (2013) emphasize that the positive correlation between capital inflows and outflows may be attributed to asymmetries between economies. Tille and Van Wincoop (2010) develop a model which shows capital inflows and outflows are positively correlated due to different optimal hedging of resident and non-resident investors against inflation or future expected returns or non-asset income. Davis and van Wincoop (2018) provide empirical evidence on the role of financial globalisation in explaining observed positive correlation.

20 Hnatkovska (2010) and Tille and van Wincoop (2010) argue that positive correlation may arise from productivity shocks even without financial frictions.
} 
The estimated coefficients for Equation 2 pertain to conditional correlations. They are conditional on given values of global and domestic factors as well as other sectoral flows. Using simple pairwise correlations may overestimate the magnitude and significance of conditional correlations. Hence, the inclusion of other sectoral flows in the conditional correlations is warranted. The estimation involves annual values from 2000-18; and robust standard errors clustered at the country level are used.

\subsection{Resident and Non-Resident Sectoral Flow Correlations}

Table 7 presents the sectoral correlations between resident and non-resident flows. To save space, the values shown in Table 7 refer to the estimated coefficients of sectoral flows regressed with other sectoral flows and controls. Several findings are noted.

First, same sector resident and non-resident flows are significantly and positively correlated. This observation is true for all sectors, including CB and GG. It implies that intra-sectoral flows are an important driver of the positive correlation between gross inflows and outflows, consistent with Davis and van Wincoop (2018) on CB flows and Davis (2015) on BK sector flows. Second, resident NFC and OFC sectoral flows positively co-move with nonresident NFC and OFC flows, in the same way that nonresident NFC and OFC flows positively correlate with resident NFC and OFC flows. Fourth, resident BK flows do not display significant co-movement with nonresident NFC and OFC flows, but nonresident BK flows are correlated with resident NFC and OFC flows. Thus, the OFC sector appears crucial in driving positive co-movements between resident and non-resident sectoral flows.

The positive sectoral correlations between sectoral gross inflows and outflows hold in advanced economies, and to a lesser extent for emerging economies. Going deeper by distinguishing equity and debt flows, both equity and debt flows seem to be driving these private sector co-movements, implying the importance of considering equity flows in assessing capital flows correlations. ${ }^{21}$

In this section, we find the significance and strength of the positive co-movement between resident and non-resident sectoral flows appear heterogenous across sectors, country income groups, and equity and debt splits. But unlike in previous studies, this section underscores the contribution of OFC sectoral flows as well as intrasectoral resident and non-resident flows in driving the positive correlations.

\section{Sectoral Flows and Capital Controls}

\subsection{Empirical Motivation}

A third research area where our sectoral approach may provide new insights is on capital controls and their effectiveness. The effectiveness of capital controls remains an unsettled question despite decades of empirical work. The literature traditionally finds that capital controls have no impact on the volume of inflows but may affect the composition of inflows, e.g., shift inflows from short-term towards longer maturity instruments. More recent work using new methodologies and more refined capital controls data still finds no impact on capital flows (Forbes et al., 2016) or at best a

21 The results are presented in Tables S7, S8 and S9 in the supplementary results. 
temporary one (Baba and Kokenyne, 2011; Pasricha et al., 2018). Some works find limited impact on a cumulative basis and in the specific post-GFC period (Ahmed and Zlate, 2014). The recent literature has thus shifted to an assessment of the impact of capital controls on other variables than flows, notably in the context of a broader discussion on the prudential role of controls. ${ }^{22}$ On the other hand, empirical evidence on capital controls for outflows remain sparse and also point to limited effectiveness with the exception of Malaysia (Magud and Reinhart, 2006) or when supported by strong fundamentals and institutions, and if existing restrictions are already comprehensive (Saborowski et al., 2014).

In this section, we complement recent work attempting to disaggregate capital flows and capital controls to yield more targeted results (Lepers and Mehigan, 2019). Specifically, we extend the analysis by looking into the effectiveness of tighter sectoral controls in reducing sectoral flows. Our approach differs from previous studies which considered aggregate or instrument-based capital control measures. A shift to a sectoral approach is neither obvious nor trivial. After all, controls are usually applied to specific transactions rather than specific sectors. Hence, all capital controls classifications to date have taken, if any, an instrument-based approach (Fernández et al., 2015; Lepers and Mehigan, 2019; Pasricha et al., 2018). But a more detailed look at controls themselves reveal the usefulness of a sectoral approach.

First, perhaps most clear-cut is the case of outward controls on domestic financial institutions, where the sector and not the transaction is the prime feature of the control. In many countries, banks, insurers, pension funds, and investment funds are subject to dedicated limits on their foreign assets as percentage of their equity or technical reserves in the case of insurers and pension funds. These institutions are engaged in different business activities and are usually supervised by different regulators, which explain to a large extent the existence of sector-specific controls. Horizontal limits on the foreign assets of banks have, however, become less common. For instance, no OECD country currently maintains such limits (OECD, 2019a). Limits on foreign assets of insurers were also dismantled in many countries, as most regulators and supervisors decided to move to risk-based rather than residency-based approaches (OECD, 2015). This is notably the case under the Solvency II framework of the European Union. Limits on pension fund investments abroad are more frequent, although gradually reduced in many countries, as highlighted by the OECD annual survey on investment regulation of pension funds (OECD, 2019b). The problem of classifying such controls in traditional instrument-based approaches is that these controls are horizontal, applying in most cases to all foreign assets of an institution. This concern is recognized by the IMF's AREAER, which dedicates a separate section to such controls (XII. Provisions Specific to the Financial Sector), and which most capital control datasets decide not to include. As these represent the bulk of outward controls, a sectoral approach thus appears appropriate.

\footnotetext{
22 The findings in this literature are also mixed. Forbes et al. (2015) find no impact of capital controls on exchange rate, inflation, equity indices, different volatilities, and interest rate differential, while Ostry et al. (2012) find that controls are associated with lower share of FX lending and lower share of portfolio debt in external liabilities. Pasricha et al. (2018) show that controls lead to increased monetary policy autonomy. In the case of Brazil, Chamon and Garcia (2016) find that the controls generally had some impact on the spread between onshore and offshore dollar interest rates but no significant effect on exchange rate appreciation. Alfaro et al. (2014) find negative microeconomic impact of controls such as harder access to funding for firms that depend on external finance, typically for SMEs.
} 
Second, another straightforward application of a sector classification on the inflow side concerns FDI and equity. FDI restrictions are largely sectoral by nature, such that foreigners are allowed to invest in certain sectors but not in others, or under certain equity limits, as shown for instance in the OECD FDI Restrictiveness Index, which provides a split along 22 economic sectors. But other controls also lend themselves naturally to a sectoral classification. Many controls apply to natural persons, some controls are specific to the banking sector in the case of credit intermediation, while many other controls, such as on external borrowing, are also specific to certain types of corporates ${ }^{23}$. For these reasons, considering the effectiveness of sector-specific capital controls on sectoral flows is warranted.

This section looks at the impact of controls imposed on a given sector on corresponding resident and non-resident sectoral flows. We ask: are sectoral controls significantly associated with lesser sectoral inflows? It is expected that the more restrictions are imposed on a sector, the lower the volume of gross sectoral flows. The analysis focuses on tightening measures, as opposed to easing or liberalising restrictions, as in most cases tightening controls were used in addressing capital flow surges. But we limit our focus to BK, NFC, and OFC sectors as these sectors are those that are most likely affected by capital control measures.

\subsection{Sectoral CFMs and Stylised Facts}

Datasets on capital controls have evolved significantly and improved in recent years. While initial datasets were aggregate indices based on a small set of binary dummies (Chinn and Ito, 2006) or later on the absence or presence of controls per instrument (Fernández et al., 2015), recent efforts have sought to move beyond indices based on the presence/absence of restrictions to capture both the extensive and intensive margins of controls, i.e., the introduction and removal of restrictions and the tightening or easing of existing measures (Lepers and Mehigan, 2019; Pasricha et al., 2018). These datasets capture the dynamic aspect of capital account liberalisation while accounting for the intensity of measures.

The dataset of Lepers and Mehigan (2019) provides the most comprehensive data on capital control adjustments with over 2,300 adjustments for a set of 51 economies since 1999. The data is mainly sourced from the yearly changes in restrictions of the IMF's AREAER reports. ${ }^{24}$ It is then complemented with additional sources, notably public and internal OECD reports in the context of the OECD Capital Movements Code mapping restrictions on cross-border transactions for the Code's adherents, as well as data from the OECD Survey on Investment Regulations of Pension Funds and similar surveys covering the insurance sector. The textual description of the policy

\footnotetext{
23 To name a few examples: India increased at several occasion quantitative limits on foreign borrowing ("ECB" program: External Commercial Borrowing) by specific sectors. South Africa allowed in 2014 subject to authorisation primary listing abroad and foreign borrowing for technology, media, telecommunication companies. Indonesia required in 2015 that nonbank corporates which borrow abroad hedge $25 \%$ of their net offshore liabilities through domestic banks. Slovenia in 1999 restricted the purchase abroad of certain shares by residents other than banks, investment funds and insurance companies.

24 The dataset includes restrictions specified in "Section XI: Capital Transactions" of the IMF AREAER reports which provide qualitative information on every policy change classified by the type of investments affected, including capital and money market instruments, derivatives, credit operations, direct investment, and "Section XII: Provisions Specific to the Financial Sector" which details restrictions specific to a type of financial institution - banks, pension funds, insurance, and funds. Coding rules are discussed in Appendix 4.
} 
change is then transformed into numerical format and classified at a granular levelby inflow/outflow and by asset category.

We use this dataset as a starting point and reclassify each of the policy adjustment along sectoral lines, i.e., whether they apply to the BK, NFC or OFC sector or a combination thereof. To match our sectoral flow data, we make the classification based on the resident sector, i.e., the investor sector for outflow controls and investee sector for inflow controls. The resulting capital controls dataset is available at daily frequency and aggregated at annual frequency. The number of capital control adjustments is summed up in each year within each sectoral control category for each country. The final annual sectoral capital controls dataset pertains to the count values of capital control adjustments.

Table 8 presents the number of capital control adjustments broken down by sectors and key instrument for all economies included in our capital controls dataset. While the number of BK and NFC controls for resident and non-resident flows appear to be in the same range, controls on resident OFC portfolio equity, portfolio debt and collective investment security are larger. Controls on direct investment are less frequent, while credit controls are (unsurprisingly) applied more to the BK sector. Figures $5 \mathrm{a}$ and $5 \mathrm{~b}$ plot yearly adjustments in non-resident and resident sectoral capital controls, from 2000 onwards; while Figures $6 \mathrm{a}$ and $6 \mathrm{~b}$ plot the cumulative adjustment in capital controls from 2000 onwards for resident and non-residents, respectively.

Several patterns stand out. First, the figures capture the well-known continuous trend of capital account liberalisation in most countries over the last two decades. For controls on resident flows, the OFC sector has clearly been most liberalised, reflecting the dismantling of limits on foreign assets by insurers and pension funds, coinciding with increasing resident OFC sectoral flows, more so for advanced economies (Figure $3 a)$. For controls on nonresident flows, the NFC sector has seen more liberalisation. Overall, restrictions on banks have been liberalised relatively less, partly due to higher initial openness in 2000. Second, the cumulative measures indicate a temporary stagnation, post-GFC, of the liberalisation of resident flows and a temporary reversal of the liberalisation of non-resident flows. Controls on nonresident flows have been used in the post-GFC period in the context of surges in emerging economies that experienced surges. Controls on resident flows were reintroduced slightly later in 2011 15, in response to deepening financial turbulence in certain countries like Greece and Iceland. From a sectoral perspective, controls on nonresident flows mostly targeted BKs, and to some extent NFCs, while controls on resident flows mostly applied to OFCs and NFCs.

\subsection{Empirical Specification}

To test the effectiveness of capital controls from a sectoral perspective, we add to our baseline specification (Equation 1) a policy variable capturing the changes in sectoral capital controls in country $i$ in year $t$. We run different regressions by matching sector-specific flows with their corresponding sector-specific controls. For instance, we regress BK non-resident flows on BK non-resident controls. Specifically, we estimate:

$$
C F_{i . j . t}=\alpha+X_{t}^{G} \beta^{\prime}+X_{i, t-1}^{D} \gamma^{\prime}+\delta \text { Controls }_{i, j, t-1}+\varepsilon_{i, j, t}
$$


where CF refers to sectoral resident and non-resident flows of country $i$, sector $j$, and time $t$ in percent of nominal GDP. X pertains to the row vector of global (G) and domestic (D) covariates, where domestic factors are lagged while global factors are included in their contemporaneous values. CONTROLS are sector $\mathrm{j}$ specific controls of country $i$ at time $t-1$. They are count variables reflecting the introduction of new restrictions or the tightening of existing ones imposed on a given sector each year (tightening); or they may reflect net changes in both tightening and easing sectoral controls on a given sector in a given year (all). The specification involves annual values from 2000-18. Robust standard errors are used.

We lag our capital controls variable for several reasons. First, lagged regressors limit potential endogeneity issues where capital controls are tightened in reaction to large capital flows. Second, capital flows are expected to react with a lag following policy implementation. Third, most of the tightening adjustments happen in the first half of the year, giving additional motivation to lag the capital controls variable. ${ }^{25}$

We first estimate Equation (3) using pooled OLS for the baseline results as the significance of capital controls might be dampened by the country fixed effects. ${ }^{26}$ Next, we estimate Equation (3) controlling for potential endogeneity in capital controls regressions, well explained in Erten et al (2019). ${ }^{27}$ To address this concern, we follow Ahnert et al. (2020), Auerbach and Gorodnichenko (2013) and Furceri et al. (2018) method of estimating seemingly "exogenous" policy shocks, thereby removing the potential for endogenous adjustments. ' We adopt their approach by running a two-stage regression framework. In the first stage, we estimate the likelihood of adjusting capital controls from a range of variables, notably capital flows themselves and our baseline regressors. We also run models with country fixed effects.

\subsection{Results and Sensitivity Tests}

Table 9 presents the results on the effectiveness of sector-specific capital controls on sectoral non-resident flows. We present the estimated coefficients, standard errors of corresponding sector-specific capital controls for BK, NFC, and OFC sectoral flows, number of observations and R-squared to save space. ${ }^{28}$ The first three columns present results from the pooled OLS model; the next three results from the two-stage approach; and the last three show the results from our fixed effects model. We run these estimations for all economies in our sample, and to a narrower subsample,

\footnotetext{
25 Other empirical studies using quarterly data consider the impact of controls over a four-quarter period. We conduct a sensitivity test to include implemented capital controls in the same year to test whether they compact capital flows quickly.

${ }^{26}$ More so as specific economies in our sample use tightening controls over the sample. This would be captured by country fixed effects. Moreover, we conducted Hausman test and the results indicate that we cannot reject the null hypothesis that random effects model is preferred. Lastly, Ahmed and Zlate (2014) and Giordani et al. (2017) were, likewise, indifferent between the use of pooled and fixed effects results.

${ }^{27}$ Endogeneity may arise as policymakers may tighten capital controls in response to high capital inflows/outflows. This would lead to downward biases estimates and could lead to coefficients going in the opposite direction (capital controls leading to increasing flows).

28 Tables S13 to $\$ 17$ in the supplementary material report the complete estimation results.
} 
focusing on emerging economies. Emerging economies are indeed more likely to struggle with volatile capital flows and resort more to the use of capital controls. ${ }^{29}$

First, for all economies, tightening sectoral controls tend to reduce BK and OFC sectoral inflows, while tightening sectoral controls (net of easing adjustments) tend to lower BK, NFC, and OFC sectoral inflows. Second, for emerging economies, tightening sectoral controls tend to reduce BK, NFC, and OFC sectoral inflows, while the net measure of tightening - easing sectoral controls is associated with significantly lower BK sector inflows. Difference between coefficients on the tightening-only measure and the net measure may point to asymmetry in the impact of tightening and easing actions on capital flows. Overall, the significance of our results highlights the importance of considering the sectors targeted by the controls in addition to the type of instruments impacted.

We conduct several tests to check the robustness of our baseline results, particularly for the emerging economies tightening controls. First, using winsorised sectoral flows data, the results hold. 30 Second, we added contemporaneous controls to test the potential impact on capital flows within the same year when the controls are introduced. The results show contemporaneous controls to be significant for NFC inflows. Third, we test for simultaneous adjustment of different sectoral controls within the same year. This will assess whether the sectoral results are driven by simultaneous restrictions in other sectors, which may indirectly impact sector specific flows. The estimates indicate that BK, NFC, and OFC sector specific controls are significantly correlated with lower corresponding sectoral inflows.

We extend the analysis by considering the impact of resident sector tightening controls on resident sector flows for emerging economies. The results are all insignificant. This may be attributed to the fact that tightening outward controls has been used much less than tightening inward controls by the 11 emerging economies in the sample (as well as the much lower number of resident flow observations) or demonstrate the relative lack of effectiveness of such controls compared to controls on inflows.

In summary, this section provides evidence that tighter capital controls on nonresident flows to BK, NFC, and OFC sectors are significantly associated with lower flows to those sectors for full and emerging economies samples. These results imply that sector specific controls, in contrast to aggregate controls, are relevant for sectoral flows. The findings appear robust to endogeneity concerns but not to fixed effects. We also find no evidence on the effectiveness of resident sector-specific controls.

\section{Concluding Remarks}

This paper seeks to revisit and deepen the study of capital flow covariates, comovements, and effectiveness of capital controls by adopting a sectoral approach to these questions. To this aim, we assemble a unique dataset of sectoral capital flows for 64 advanced and emerging economies, from 2000-18, including direct, portfolio,

\footnotetext{
29 The sample for non-resident sectoral flows includes 23 emerging economies, namely: Argentina, Brazil, Bulgaria, Chile, China, Colombia, Croatia, Hungary, India, Indonesia, Malaysia, Mexico, Peru, Philippines, Poland, Romania, Russia, Serbia, South Africa, Thailand, Turkey, Ukraine, and Uruguay..

30 Sectoral flows data are winsorised at the top and bottom $10 \%$ of the sample.
} 
and other investment to and from five sectors: namely, central banks (CB), general government (GG), banks (BKs), non-financial corporates (NFCs) and other financial corporates (OFCs). Secondly, we construct a sectoral capital controls dataset classifying adjustments in capital controls along the five sectors studied over the same time.

Armed with such data, we show that: First, while global financial cycles and domestic output growth generally drive private sector flows, there are notable differences in the way certain sectoral flows respond to these variables. Specifically, we find that OFC resident outflows are countercyclical to domestic growth. Second, intra-sectoral co-movement and movements in OFC sectoral flows explain a large part of the observed positive correlation between gross inflows and outflows found in previous studies. Third, we find some evidence that the introduction or tightening of capital controls applied to BKs, NFCs, and OFCs appear effective in reducing the volume of capital inflows to these sectors.

Our findings highlight the usefulness of a sectoral approach in the understanding of capital flows and raise several implications for researchers and policymakers. Research on capital flow covariates and co-movements must consider potentially divergent sectoral behaviour of sectors. As for policy, we show that the effectiveness of capital controls may depend on the sector on which they are imposed. This is notably of relevance to the ongoing discussion on the appropriateness of macroprudential policy beyond banking (See e.g. ESRB 2016). 


\section{REFERENCES}

Ahmed, S., Zlate, A., 2014. Capital flows to emerging market economies: A brave new world? J. Int. Money Financ. 48, 221-248.

https://doi.org/10.1016/j.jimonfin.2014.05.015

Ahnert, T., Forbes, K., Friedrich, C., Reinhardt, D., 2020. Macroprudential FX Regulations: Shifting the Snowbanks of FX Vulnerability? Journal of Financial Economics, forthcoming.

Aiyar, S., Calomiris, C.W., Wieladek, T., 2012. Does Macro-Pru Leak? Evidence from a UK Policy Experiment. NBER Work. Pap.

Alfaro, C., Laura, A., Chari, F., Kanczuk, F., 2014. The Real Effects of Capital Controls: Financial Constraints, Exporters, and Firm Investment. Harvard Bus. Sch. Work. Pap.

Alfaro, L., Kalemli-Ozcan, S., Volosovych, V., 2014. Sovereigns, upstream capital flows, and global imbalances. J. Eur. Econ. Assoc. 12, 1240-1284. https://doi.org/10.1111/jeea.12106

Araujo, J.D., David, A.C., van Hombeeck, C., Papageorgiou, C., 2017. Joining the club? Procyclicality of private capital inflows in lower income developing economies. J. Int. Money Financ. 70, 157-182. https://doi.org/10.1016/j.jimonfin.2016.08.006

Auerbach, A.J., Gorodnichenko, Y., 2013. Output Spillovers from Fiscal Policy. Am. Econ. Rev. 103, 141-146. https://doi.org/10.1257/aer.103.3.141

Avdjiev, S., Chui, M., Shin, H.S., 2014. Non-financial corporations from emerging market economies and capital flows, BIS Working Paper.

Avdjiev, S., Hardy, B., Kalemli-Ozcan, S., Servén, L., 2018. Gross capital flows by banks, corporates and sovereigns. BIS Work. Pap.

Baba, C., Kokenyne, A., 2011 . Effectiveness of Capital Controls in Selected Emerging Markets in the 2000s. IMF Work. Pap.

Broner, F., Didier, T., Erce, A., Schmukler, S.L., 2013. Gross capital flows: Dynamics and crises. J. Monet. Econ. 60, 113-133.

https://doi.org/10.1016/j.jmoneco.2012.12.004

Byrne, J.P., Fiess, N., 2016. International capital flows to emerging markets: National and global determinants. J. Int. Money Financ. 61, 82-100. https://doi.org/10.1016/j.jimonfin.2015.11.005

Calderón, C., Kubota, M., 2013. Sudden stops: Are global and local investors alike? J. Int. Econ. 89, 122-142. https://doi.org/10.1016/j.jinteco.2012.05.010

Calvo, G.A., Leiderman, L., Reinhart, C.M., 1993. Capital Inflows and Real Exchange Rate Appreciation in Latin America: The Role of External Factors, IMF Staff Papers. International Monetary Fund.

Cavallo, E.A., Frankel, J.A., 2008. Does openness to trade make countries more vulnerable to sudden stops, or less? Using gravity to establish causality. J. Int. Money Financ. 27, 1430-1452. https://doi.org/10.1016/j.jimonfin.2007.10.004

Cerutti, E., Claessens, S., Puy, D., 2019. Push factors and capital flows to emerging markets: why knowing your lender matters more than fundamentals. J. Int. Econ. 119, 133-149. https://doi.org/10.1016/J.JINTECO.2019.04.006

Cerutti, E., Hee Hong, G., 2018. Portfolio Inflows Eclipsing Banking Inflows: Alternative Facts? IMF Working Paper.

Chamon, M., Garcia, M., 2016. Capital controls in Brazil: Effective? J. Int. Money Financ. 61, 163-187. https://doi.org/10.1016/j.jimonfin.2015.08.008

Chinn, M.D., Ito, H., 2006. What matters for financial development? Capital controls, institutions, and interactions. J. Dev. Econ. 81, 163-192. 
https://doi.org/10.1016/j.jdeveco.2005.05.010

Chuhan, P., Claessens, S., Mamingi, N., 1998. Equity and bond flows to Latin America and Asia: the role of global and country factors. J. Dev. Econ. 55, 439-463.

Davis, J.S., 2015. The Cyclicality of (Bilateral) Capital Inflows and Outflows, Federal Reserve Bank of Dallas, Globalization and Monetary Policy Institute Working Paper.

Davis, J.S., Van Wincoop, E., 2018. Globalization and the increasing correlation between capital inflows and outflows. J. Monet. Econ. 100, 83-100. https://doi.org/10.1016/j.jmoneco.2018.07.009

European Systemic Risk Board. (2016). Macroprudential policy beyond banking: an ESRB strategy paper.

Erten, B., Korinek, A., \& Ocampo, J. A. (2019). Capital controls: theory and evidence (NBER Working Papers). http://www.nber.org/papers/w26447

ESRB (2016). Macroprudential policy beyond banking: an ESRB strategy paper

Fernández, A., Klein, M.W., Rebucci, A., Schindler, M., Uribe, M., 2015. Capital Control Measures: A New Dataset, IMF Working Paper.

Forbes, K., Fratzscher, M., Kostka, T., Straub, R., 2016. Bubble thy neighbour: Portfolio effects and externalities from capital controls. J. Int. Econ. 99, 85-104. https://doi.org/10.1016/J.JINTECO.2015.12.010

Forbes, K., Fratzscher, M., Straub, R., Chari, A., Dominguez, K., Frankel, J., Garcia, M., Ghosh, R., Kaminsky, G., Klein, M., Obstfeld, M., Ostry, J., Reinhart, V., Rey, H., Rose, A., Schmidt-Hebbel, K., Sgheri, S., Yetman, J., 2015. Capital-flow management measures: What are they good for? J. Int. Econ. 96, S76-S97. https://doi.org/10.1016/j.jinteco.2014.11.004

Forbes, K.J., Warnock, F.E., 2012. Capital flow waves: Surges, stops, flight, and retrenchment. J. Int. Econ. 88, 235-251. https://doi.org/10.1016/j.jinteco.2012.03.006

Forbes, K. J., \& Warnock, F. E. (2020). Capital Flow Waves-Or Ripples? Extreme Capital Flow Movements Since The Crisis, NBER Working Paper.

Fratzscher, M., 2012. Capital flows, push versus pull factors and the global financial crisis. J. Int. Econ. 88, 341-356. https://doi.org/10.1016/j.jinteco.2012.05.003

Furceri, D., Loungani, P., Zdzienicka, A., 2018. The effects of monetary policy shocks on inequality. J. Int. Money Financ. 85, 168-186. https://doi.org/10.1016/j.jimonfin.2017.11.004

Ghosh, A.R., Qureshi, M.S., Kim, J. II, Zalduendo, J., 2014. Surges. J. Int. Econ. 92, 266285. https://doi.org/10.1016/j.jinteco.2013.12.007

Giordani, P.E., Ruta, M., Weisfeld, H., Zhu, L., 2017. Capital flow deflection. J. Int. Econ. 105, 102-1 18. https://doi.org/10.1016/j.jinteco.2016.12.007

Gori, F., Lepers, E., \& Mehigan, C. (2020). Capital Flow Deflection under the Magnifying Glass, OECD Economics Department Working Papers. https://dx.doi.org/10.1787/398180d0-en

Hnatkovska, V., 2010. Home bias and high turnover: Dynamic portfolio choice with incomplete markets. J. Int. Econ. 80, 113-128.

https://doi.org/10.1016/j.jinteco.2009.06.006

Hoggarth, G., Jung, C., \& Reinhardt, D. (2016). Capital inflows-the good, the bad and the bubbly. BoE Financial Stability Paper.

Kaminsky, G.L., Reinhart, C.M., Végh, C.A., 2004. When It Rains, It Pours: Procyclical Capital Flows and Macroeconomic Policies, Source: NBER Macroeconomics Annual.

Lane, P. (2020). The market stabilisation role of the pandemic emergency purchase 
programme. The ECB Blog.

https://www.ecb.europa.eu/press/blog/date/2020/html/ecb.blog200622 14c42 69b9e.en.html

Lane, P.R., McQuade, P., 2014. Domestic Credit Growth and International Capital

Flows. Scand. J. Econ. 116, 218-252. https://doi.org/10.1111/sjoe.12038

Lepers, E., Mehigan, C., 2019. The broad policy toolkit for financial stability:

Foundations, fences, and fire doors. OECD Work. Pap. Int. Invest.

https://doi.org/10.1787/9188f06a-en

Li, S., de Haan, J., Scholtens, B., 2018. Surges of international fund flows. J. Int. Money

Financ. 82, 97-1 19. https://doi.org/10.1016/j.jimonfin.2018.01.002

Luna, P., Hardy, B., 2019. Non-bank counterparties in international banking, BIS

Quarterly Review.

Magud, N., Reinhart, C., 2006. Capital Controls: An Evaluation, NBER Working Paper Series.

McCauley, R.N., Bénétrix, A.S., McGuire, P.M., von Peter, G., 2019. Financial deglobalisation in banking? J. Int. Money Financ. 94, 116-131.

https://doi.org/10.1016/J.JIMONFIN.2019.01.011

McQuade, P., Schmitz, M., 2017. The great moderation in international capital flows:

A global phenomenon? J. Int. Money Financ. 73, 188-212.

https://doi.org/10.1016/j.jimonfin.2017.02.027

Mercado, R. V., Park, C.Y., 2011 . What Drives Different Types of Capital Flows and their Volatilities in Developing Asia? Int. Econ. J. 25, 655-680.

https://doi.org/10.1080/10168737.2011.636628

Mercado, R. V, 2018. Not all surges of gross capital inflows are alike. J. Econ. Stud. https://doi.org/10.1108/JES-01-2017-0007

Milesi-Ferretti, G.-M., Tille, C., 2011. The great retrenchment: international capital flows during the global financial crisis. Econ. Policy.

OECD, 2019a. OECD Code of Liberalisation of Capital Movements.

OECD, 2019b. 2019-Survey-Investment-Regulation-Pension-Funds.

OECD, 2015. Regulation of Insurance Company and Pension Fund Investment OECD Report to G20 Finance Ministers and Central Bank Governors.

Ostry, J.D., Ghosh, A.R., Chamon, M., Qureshi, M.S., 2012. Tools for managing financial-stability risks from capital inflows. J. Int. Econ. 88, 407-421. https://doi.org/10.1016/j.jinteco.2012.02.002

Pasricha, G. K. (2017). Policy rules for capital controls. BIS Working Paper.

Pasricha, G.K., Falagiarda, M., Bijsterbosch, M., Aizenman, J., 2018. Domestic and multilateral effects of capital controls in emerging markets. J. Int. Econ. 115, 4858. https://doi.org/10.1016/J.JINTECO.2018.08.005

Patalano, R., Roulet, C., 2020. Structural developments in global financial intermediation: The rise of debt and non-bank credit intermediation. OECD Work. Pap. Financ. Insur. Priv. Pensions. https://doi.org/10.1787/daa87f13-en

Puy, D., 2016. Mutual funds flows and the geography of contagion. J. Int. Money Financ. 60, 73-93. https://doi.org/10.1016/j.jimonfin.2015.06.014

Reinhart, C.M., Reinhart, V.R., 2008. 1 Capital Flow Bonanzas: An Encompassing View of the Past and Present. NBER Int. Semin. Macroecon. 5, 9-62.

https://doi.org/10.1086/595995

Rey, H., 2016. International channels of transmission of monetary policy and the mundellian trilemma. IMF Econ. Rev. https://doi.org/10.1057/imfer.2016.4

Rey, H., 2013. Dilemma not Trilemma: The Global Financial Cycle and Monetary Policy Independence, Jackson Hole Conference Proceedings, Kansas City Fed.

Saborowski, C., Sanya, S., Weisfeld, H., Yepez, J., 2014. Effectiveness of Capital 
Outflow Restrictions, IMF Working Papers.

Sarno, L., Tsiakas, I., Ulloa, B., 2016. What drives international portfolio flows? J. Int. Money Financ. 60, 53-72. https://doi.org/10.1016/j.jimonfin.2015.03.006

Shirota, T., 2015. What is the major determinant of cross-border banking flows? J. Int. Money Financ. 53, 137-147. https://doi.org/10.1016/j.jimonfin.2015.01.001

Tille, C., van Wincoop, E., 2010. International capital flows. J. Int. Econ. 80, 157-175. https://doi.org/10.1016/j.jinteco.2009.11.003

Wang, Y., 2018. Fickle capital flows and retrenchment: Evidence from bilateral banking data. J. Int. Money Financ. 87, 1-21.

https://doi.org/10.1016/j.jimonfin.2018.05.005 
Figures and Tables

Figure 1: Sectoral Resident Flows (US\$ billion)

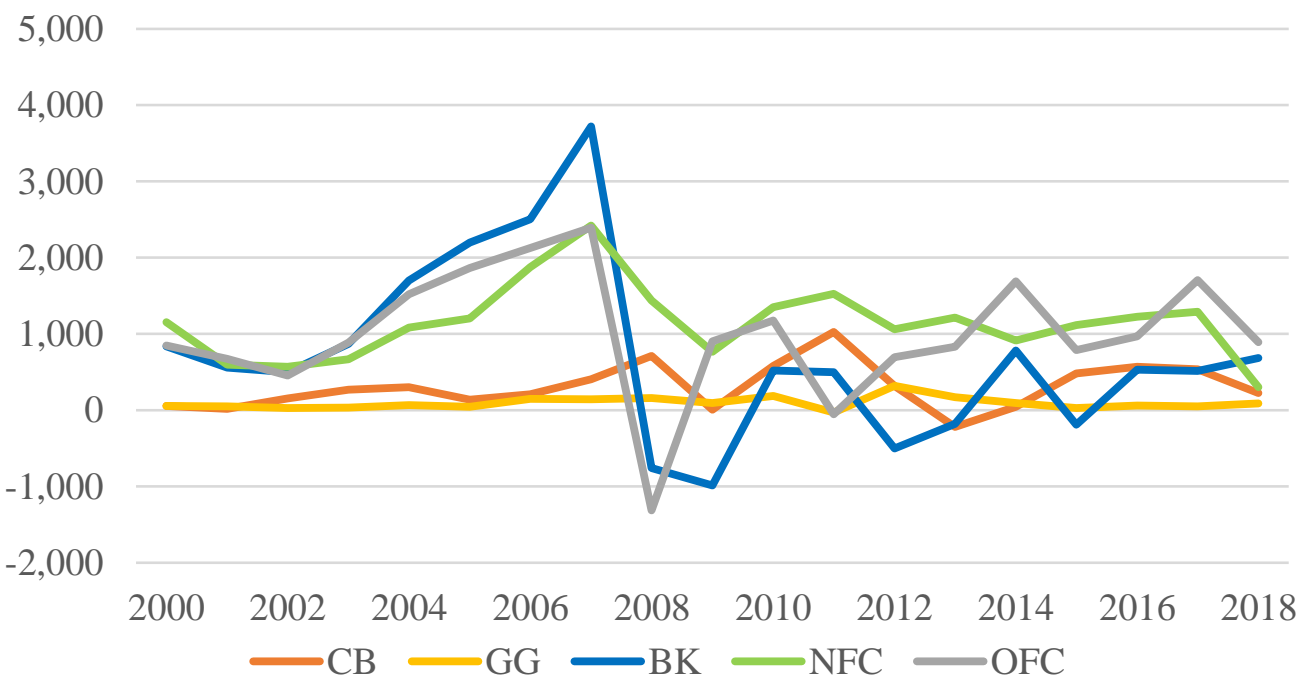

Notes: Resident sectoral flows are financial account assets of central bank (CB), general government (GG), banks (BK), non-financial corporates (NFC), and other financial corporate (OFC) across types of investments including direct, portfolio, and other investments.

Source: Data taken from IMF's Balance of Payments Statistics and authors' computations.

Figure 2: Sectoral Non-Resident Flows (US\$ billion)

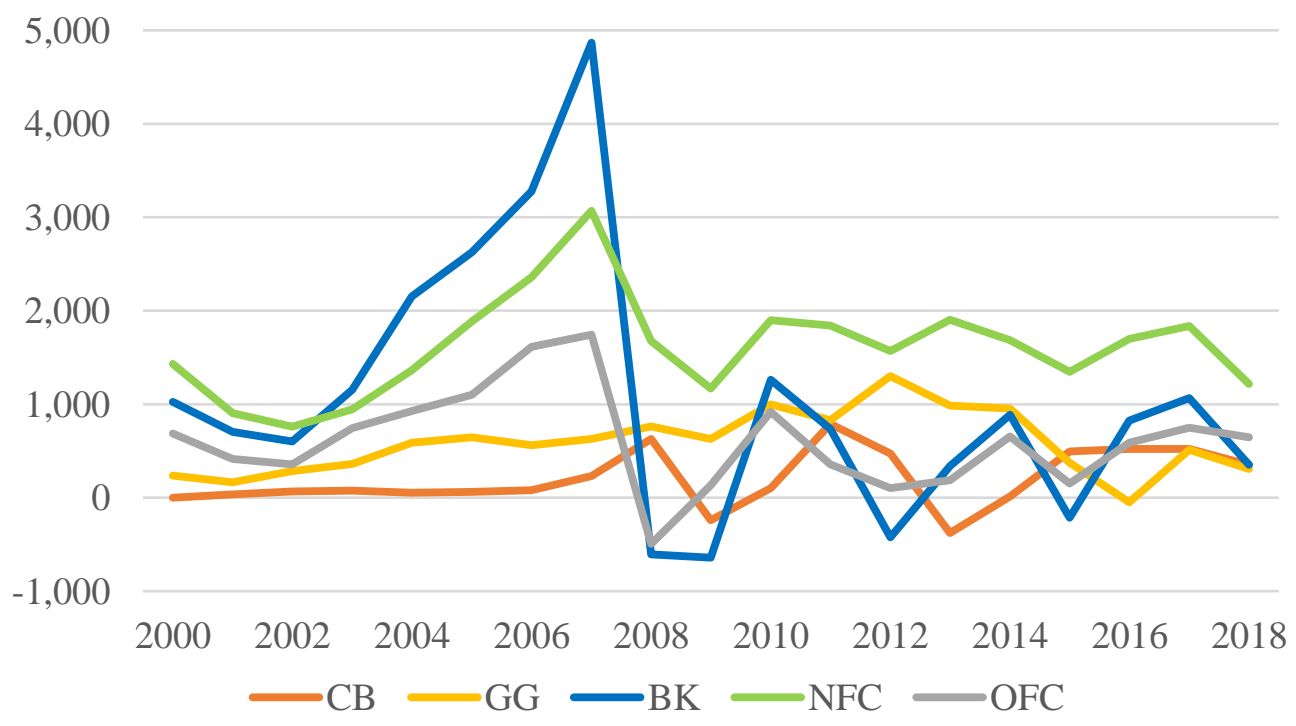

Notes: Non-resident sectoral flows are financial account liabilities of central bank (CB), general government (GG), banks (BK), non-financial corporates (NFC), and other financial corporate (OFC) across types of investments including direct, portfolio, and other investments.

Source: Data taken from IMF's Balance of Payments Statistics and authors' computations. 
Figure 3a: Sectoral Resident Flows (US\$ billion), Advanced Economies

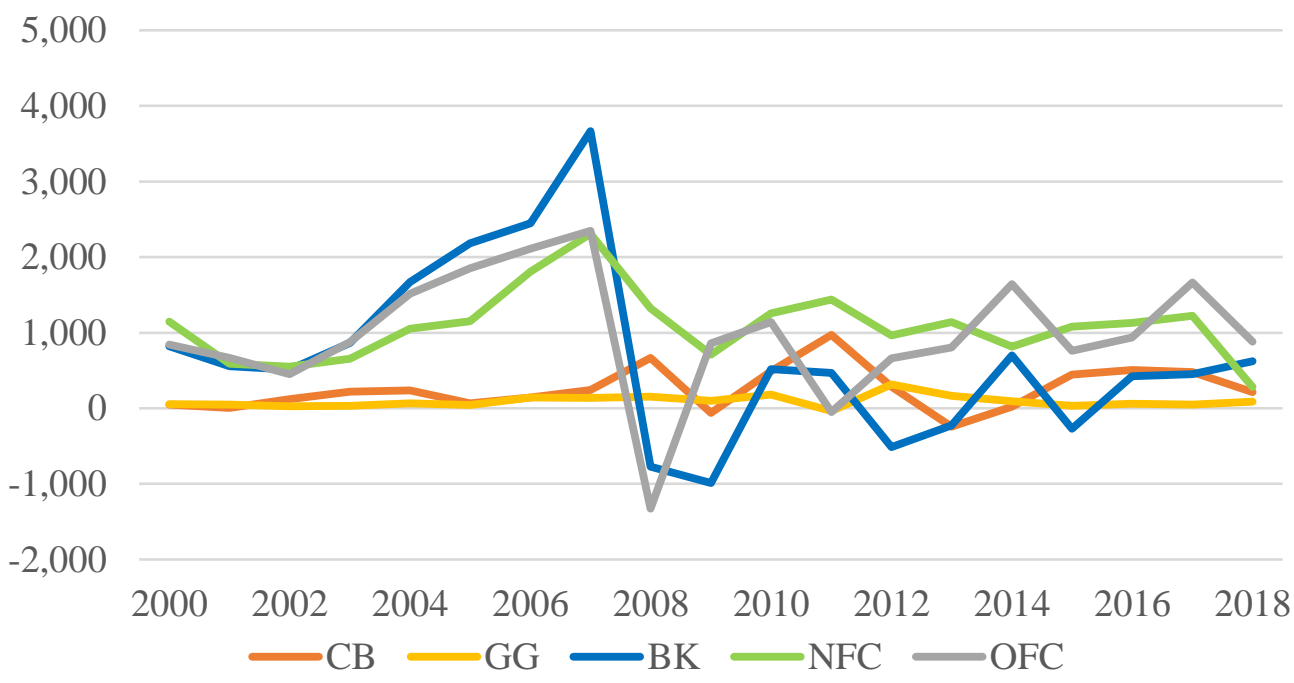

Notes: Resident sectoral flows are financial account assets of central bank (CB), general government (GG), banks (BK), non-financial corporates (NFC), and other financial corporate (OFC) across types of investments including direct, portfolio, and other investments. Refer to Appendix 2 for the list of advanced economies.

Source: Data taken from IMF's Balance of Payments Statistics and authors' computations.

Figure 3b: Sectoral Non-Resident Flows (US\$ billion), Advanced Economies

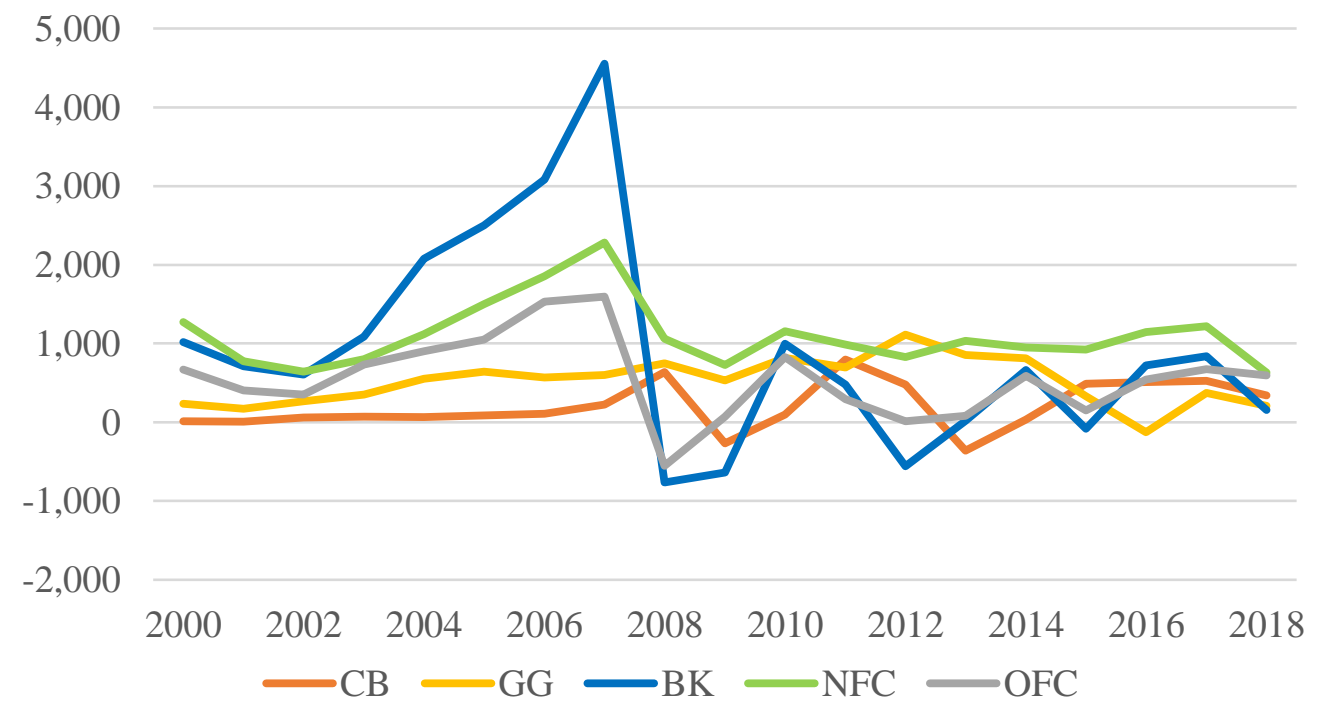

Notes: Non-resident sectoral flows are financial account liabilities of central bank (CB), general government (GG), banks (BK), non-financial corporates (NFC), and other financial corporate (OFC) across types of investments including direct, portfolio, and other investments. Refer to Appendix 2 for the list of advanced economies.

Source: Data taken from IMF's Balance of Payments Statistics and authors' computations. 
Figure 4a: Sectoral Resident Flows (US\$ billion), Emerging Economies

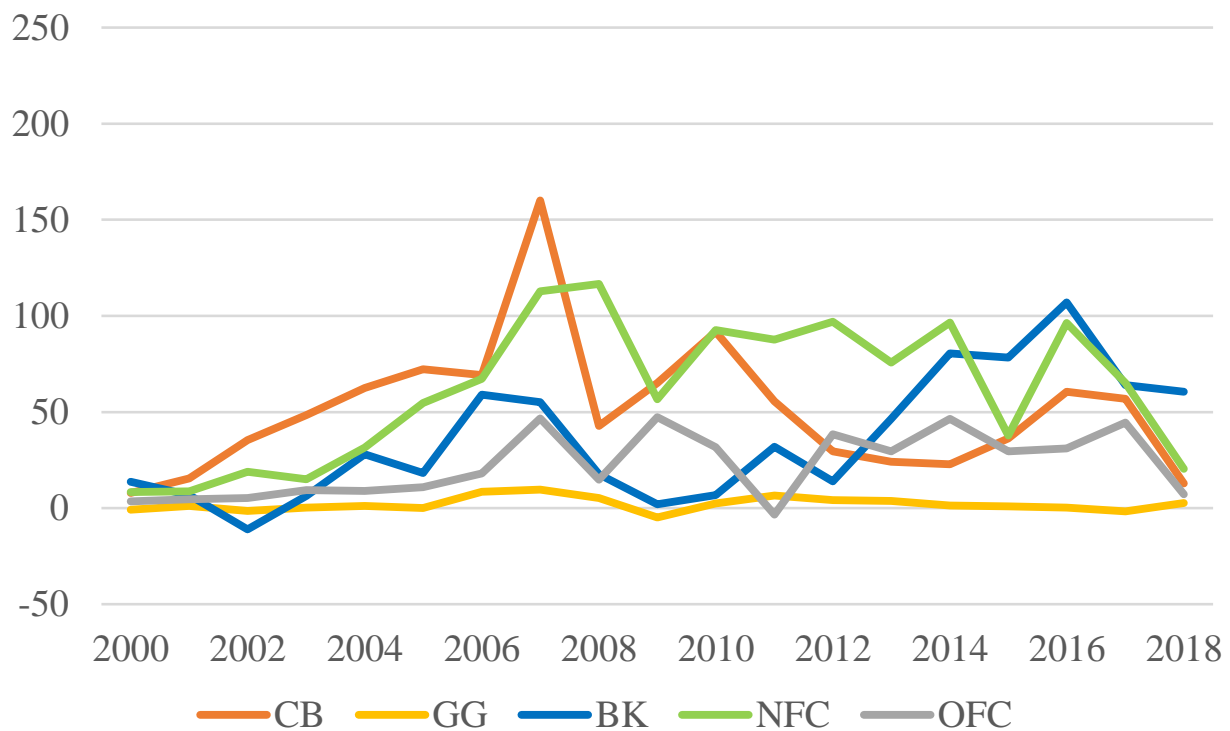

Notes: Resident sectoral flows are financial account liabilities of central bank (CB), general government (GG), banks (BK), non-financial corporates (NFC), and other financial corporate (OFC) across types of investments including direct, portfolio, and other investments. Refer to Appendix 2 for the list of emerging economies. Source: Data taken from IMF's Balance of Payments Statistics and authors' computations.

Figure 4b: Sectoral Non-Resident Flows (US\$ billion), Emerging Economies

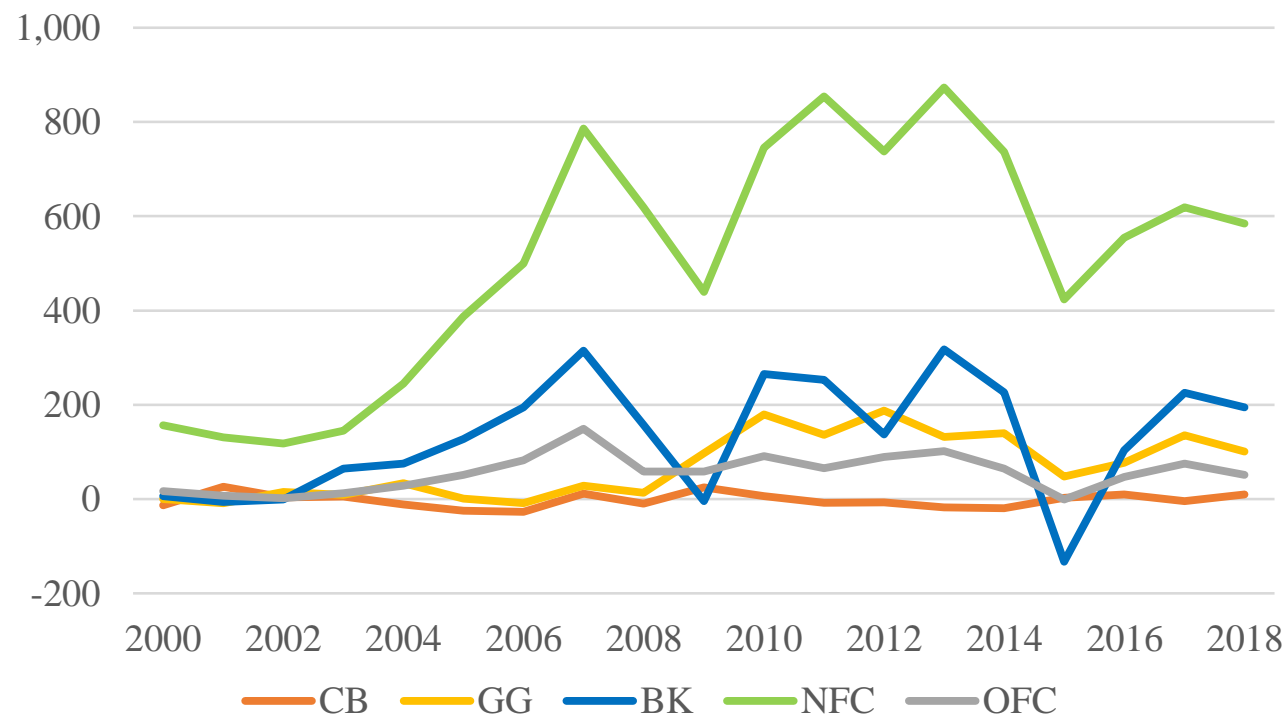

Notes: Non-resident sectoral flows are financial account liabilities of central bank (CB), general government (GG), banks (BK), non-financial corporates (NFC), and other financial corporate (OFC) across types of investments including direct, portfolio, and other investments. Refer to Appendix 2 for the list of emerging economies.

Source: Data taken from IMF's Balance of Payments Statistics and authors' computations. 
Figure 5a: Yearly Adjustments of Sectoral Controls on Sectoral Non-Resident Flows

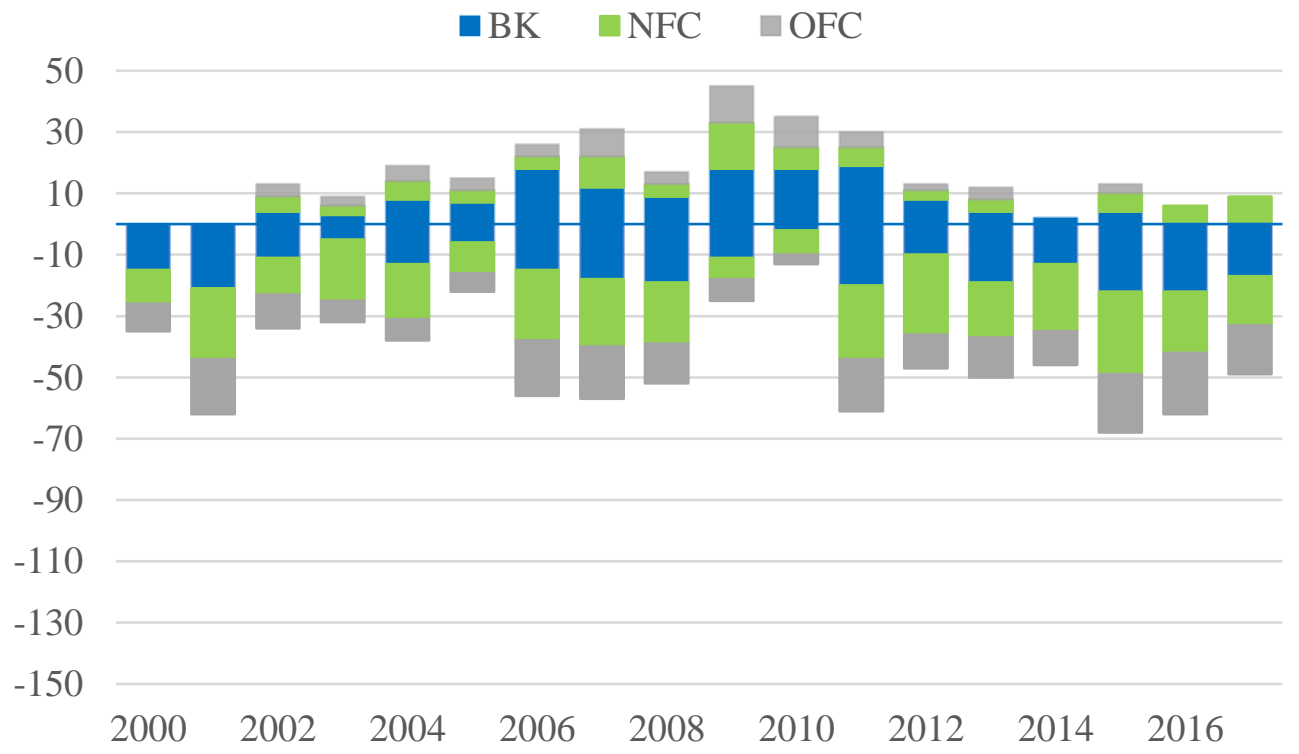

Figure 5b: Yearly Adjustments of Sectoral Controls on Sectoral Resident Flows

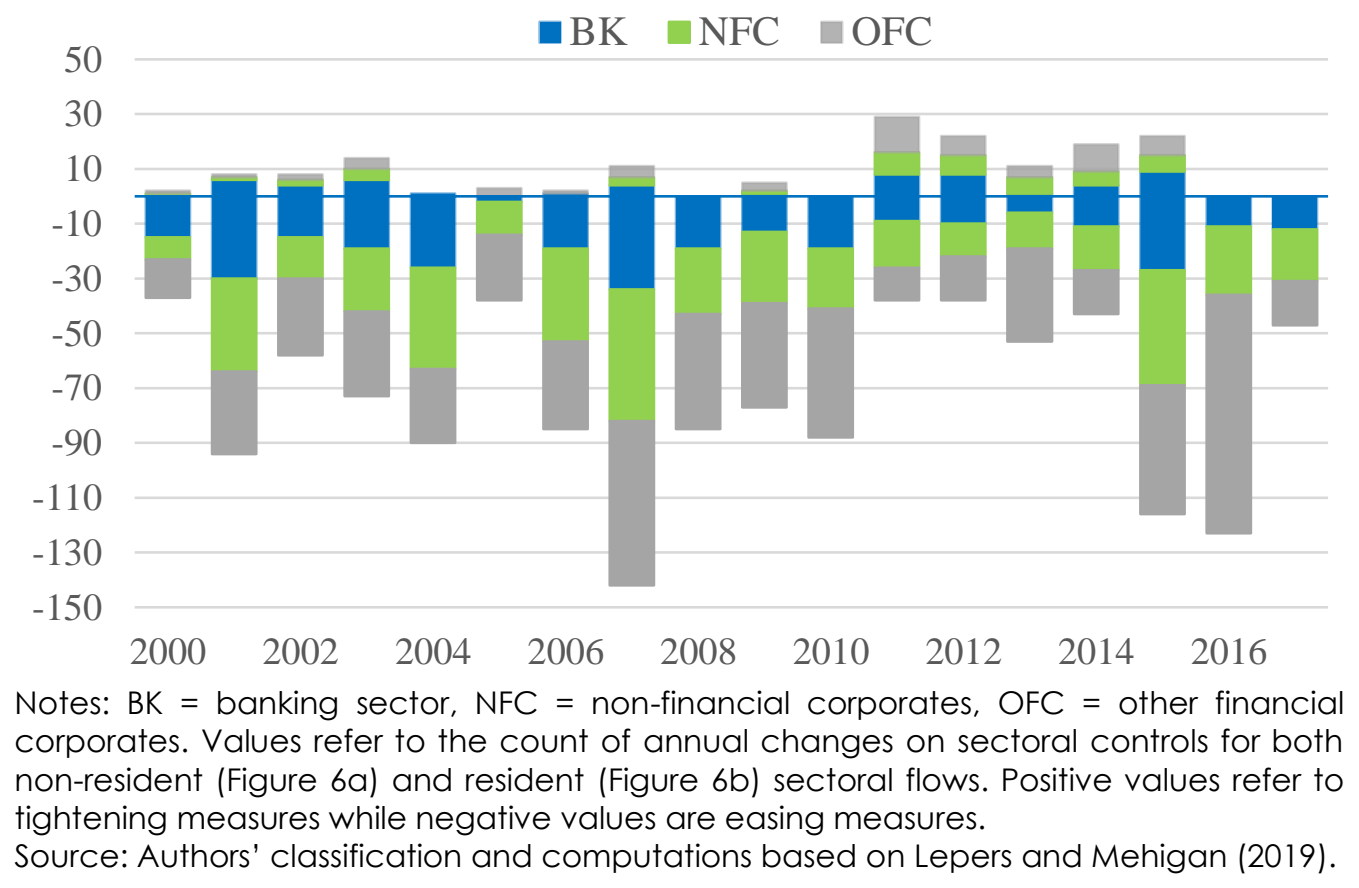


Figure 6a: Cumulative Adjustments of Sectoral Controls on Non-Resident Flows

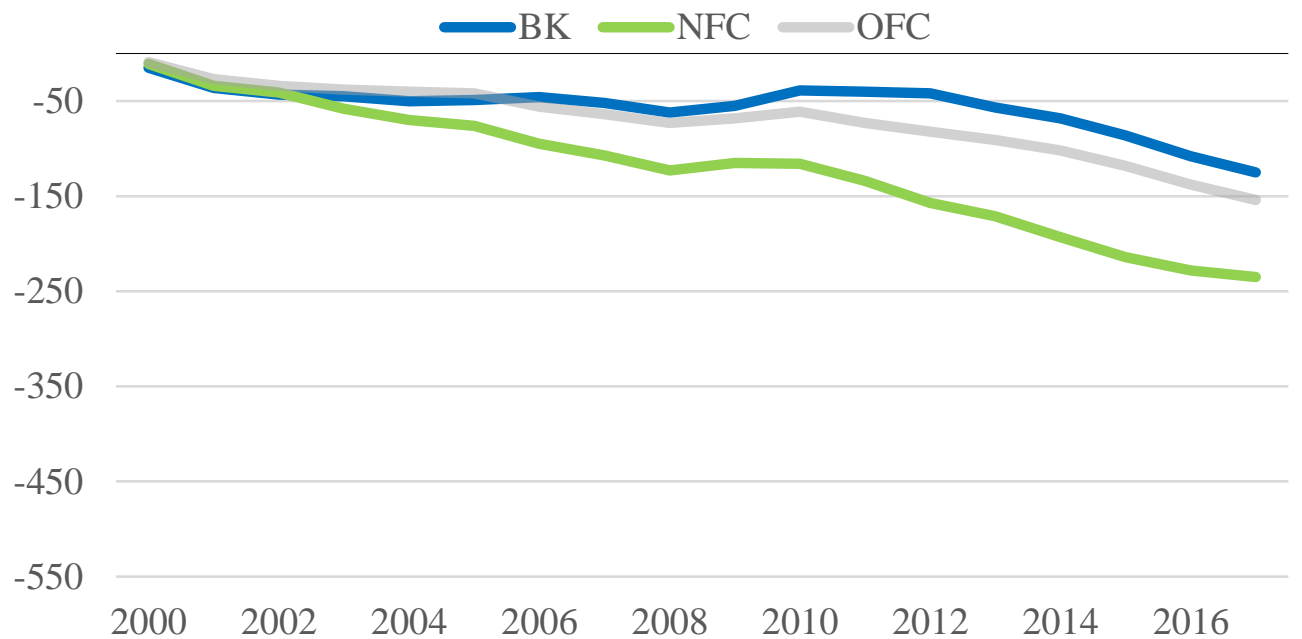

Figure 6b: Cumulative Adjustments of Sectoral Controls on Resident Flows

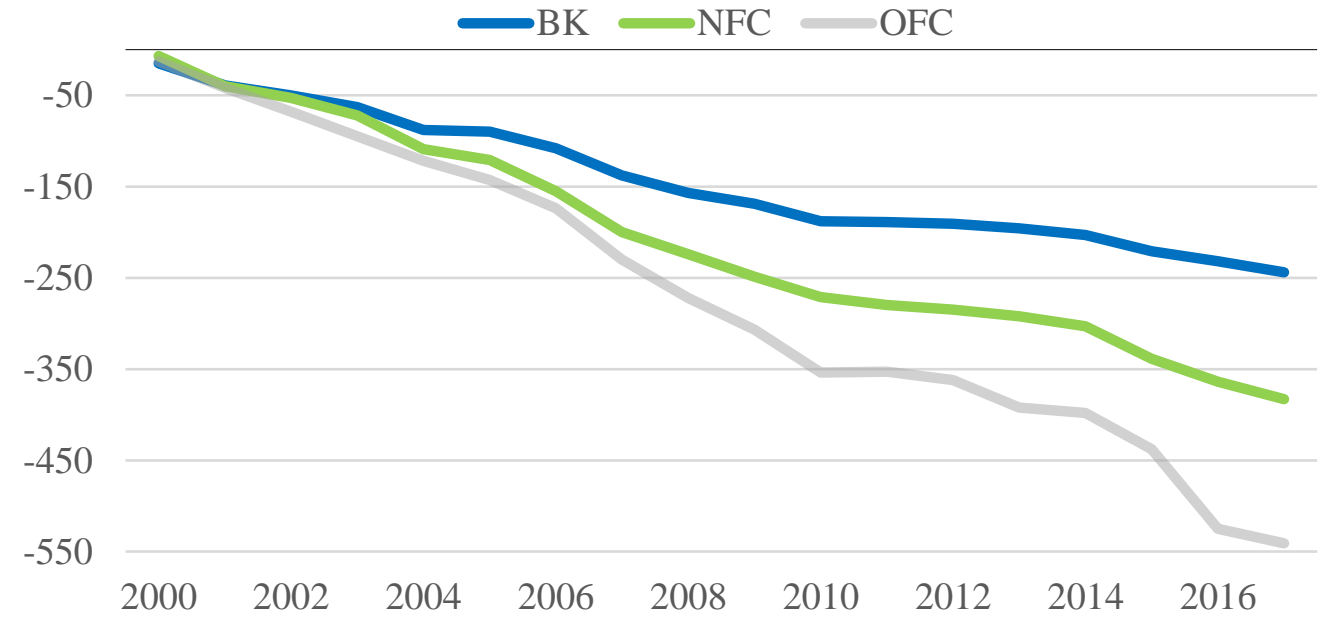

Notes: $B K=$ banking sector, $N F C=$ non-financial corporates, $O F C=$ other financial corporates. Values refer to the cumulative count of sectoral controls for both non-resident (Figure 7a) and resident (Figure 7b) sectoral flows. Declining values pertain to easing measures.

Source: Authors' classification and computations based on Lepers and Mehigan (2019). 
Table 1: Descriptive statistics: Dependent Variables and regressions

\begin{tabular}{lrrrrr}
\hline & Obs & Mean & Std. Dev. & Min & Max \\
\hline \hline & Total Sectoral Flows & & & \\
\hline Resident Flows - CB & 772 & 1.47 & 3.5 & -24.0 & 26.0 \\
Resident Flows - GG & 703 & 0.61 & 2.6 & -7.5 & 29.3 \\
Resident Flows - BK & 772 & 1.99 & 6.7 & -53.2 & 51.8 \\
Resident Flows - NFC & 772 & 3.25 & 6.0 & -24.5 & 59.8 \\
Resident Flows - OFC & 762 & 1.97 & 3.3 & -20.0 & 22.4 \\
\hline Non-Resident Flows - CB & 1,068 & 0.30 & 2.9 & -27.9 & 34.1 \\
Non-Resident Flows - GG & 1,191 & 1.23 & 2.9 & -20.9 & 35.5 \\
Non-Resident Flows - BK & 1,198 & 2.26 & 7.4 & -50.8 & 87.2 \\
Non-Resident Flows - NFC & 1,198 & 4.16 & 4.4 & -14.2 & 46.0 \\
Non-Resident Flows - OFC & 1,181 & 0.72 & 2.0 & -12.1 & 23.9 \\
\hline \hline \multicolumn{7}{c}{ Global Factors } \\
\hline Global GDP Growth & 1,216 & 3.86 & 1.3 & -0.1 & 5.6 \\
Global Liquidity Index & 1,216 & 46.32 & 6.9 & 35.6 & 63.4 \\
VIX & 1,216 & 19.94 & 6.9 & 11.0 & 40.0 \\
Global Commodity Price Index & 1,216 & 117.07 & 40.2 & 56.1 & 182.7 \\
\hline \hline \multicolumn{7}{c}{ Domestic Factors } \\
\hline Domestic GDP Growth & 1,214 & 3.36 & & \\
\hline Not Resident and nOn-sident
\end{tabular}

Notes: Resident and non-resident sectoral flows are financial account assets and liabilities, respectively, of central bank (CB), general government (GG), banks (BK), nonfinancial corporates (NFC), and other financial corporate (OFC). Values for sectoral flows are in percent of nominal GDP, taken from the IMF's World Economic Outlook Database. Data on global GDP growth are year-on-year changes of world real GDP. Global liquidity, VIX, and global commodity price are indices. Data on domestic GDP growth are year-on-year changes of domestic real GDP. Refer to Appendix 3 for data definition and sources.

Source: Authors' computations. 
Table 2: Sectoral Flows Covariates - Baseline

\begin{tabular}{|c|c|c|c|c|c|c|c|c|c|c|}
\hline & \multicolumn{5}{|c|}{ Non-Resident Flows } & \multicolumn{5}{|c|}{ Resident Flows } \\
\hline & (1) & (2) & (3) & (4) & (5) & (6) & (7) & (8) & (9) & (10) \\
\hline & $\mathbf{C B}$ & GG & $\mathbf{B K}$ & NFC & OFC & $\mathbf{C B}$ & GG & $\mathbf{B K}$ & NFC & OFC \\
\hline Global GDP Growth & $\begin{array}{l}-0.026 \\
(0.120)\end{array}$ & $\begin{array}{l}0.055 \\
(0.092)\end{array}$ & $\begin{array}{l}0.908 * * * \\
(0.245)\end{array}$ & $\begin{array}{l}0.641 * * * \\
(0.127)\end{array}$ & $\begin{array}{l}0.208 * * * \\
(0.068)\end{array}$ & $\begin{array}{l}-0.075 \\
(0.149)\end{array}$ & $\begin{array}{l}0.147 \\
(0.116)\end{array}$ & $\begin{array}{l}0.961 * * * \\
(0.283)\end{array}$ & $\begin{array}{l}0.649 * * * \\
(0.176)\end{array}$ & $\begin{array}{l}0.018 \\
(0.129)\end{array}$ \\
\hline Global Liquidity & $\begin{array}{l}0.003 \\
(0.010)\end{array}$ & $\begin{array}{l}0.011 \\
(0.014)\end{array}$ & $\begin{array}{l}0.202 * * * \\
(0.043)\end{array}$ & $\begin{array}{l}0.102 * * * \\
(0.026)\end{array}$ & $\begin{array}{l}0.032 * * * \\
(0.011)\end{array}$ & $\begin{array}{l}0.034 \\
(0.021)\end{array}$ & $\begin{array}{l}0.005 \\
(0.008)\end{array}$ & $\begin{array}{l}0.174 * * * \\
(0.037)\end{array}$ & $\begin{array}{l}0.130 * * * \\
(0.046)\end{array}$ & $\begin{array}{l}0.071 * * * \\
(0.019)\end{array}$ \\
\hline VIX & $\begin{array}{l}-0.007 \\
(0.026)\end{array}$ & $\begin{array}{l}0.057 * * * \\
(0.017)\end{array}$ & $\begin{array}{l}-0.066^{*} \\
(0.034)\end{array}$ & $\begin{array}{l}0.048 \\
(0.031)\end{array}$ & $\begin{array}{l}-0.001 \\
(0.009)\end{array}$ & $\begin{array}{l}-0.028 \\
(0.033)\end{array}$ & $\begin{array}{l}0.013 \\
(0.010)\end{array}$ & $\begin{array}{l}-0.071 \\
(0.044)\end{array}$ & $\begin{array}{l}0.030 \\
(0.033)\end{array}$ & $\begin{array}{l}-0.059^{* * *} \\
(0.018)\end{array}$ \\
\hline Global Commodity Price & $\begin{array}{l}0.001 \\
(0.002)\end{array}$ & $\begin{array}{l}0.010 * * * \\
(0.003)\end{array}$ & $\begin{array}{l}-0.029 * * * \\
(0.008)\end{array}$ & $\begin{array}{l}0.003 \\
(0.006)\end{array}$ & $\begin{array}{l}-0.006^{* *} \\
(0.002)\end{array}$ & $\begin{array}{l}-0.005 \\
(0.006)\end{array}$ & $\begin{array}{l}-0.001 \\
(0.002)\end{array}$ & $\begin{array}{l}-0.030 * * \\
(0.011)\end{array}$ & $\begin{array}{l}-0.003 \\
(0.004)\end{array}$ & $\begin{array}{l}-0.019 * * * \\
(0.005)\end{array}$ \\
\hline Domestic GDP Growth & $\begin{array}{l}0.032 \\
(0.031) \\
\end{array}$ & $\begin{array}{l}-0.153 * * * \\
(0.027)\end{array}$ & $\begin{array}{l}0.329 * * * \\
(0.078)\end{array}$ & $\begin{array}{l}0.253 * * * \\
(0.050)\end{array}$ & $\begin{array}{l}0.063 * * * \\
(0.014)\end{array}$ & $\begin{array}{l}-0.009 \\
(0.042) \\
\end{array}$ & $\begin{array}{l}0.003 \\
(0.026) \\
\end{array}$ & $\begin{array}{l}0.096 * * \\
(0.045)\end{array}$ & $\begin{array}{l}0.142 * * \\
(0.059)\end{array}$ & $\begin{array}{l}-0.041 * * \\
(0.019)\end{array}$ \\
\hline Observations & 1068 & 1191 & 1198 & 1198 & 1181 & 772 & 703 & 772 & 772 & 762 \\
\hline R-squared & 0.063 & 0.232 & 0.332 & 0.390 & 0.239 & 0.114 & 0.580 & 0.202 & 0.441 & 0.388 \\
\hline Country F.E. & Yes & Yes & Yes & Yes & Yes & Yes & Yes & Yes & Yes & Yes \\
\hline
\end{tabular}

Notes: $C B=$ central bank; GG = general government; BK = banks; NFC = non-financial corporates; and OFC = other financial corporate. Dependent variables are sectoral flows in percent of nominal GDP for non-resident (column 1-5) and resident (column 6-10) sectoral flows. Regressors are in contemporaneous values, except for domestic GDP growth which was lagged. All specifications include country fixed effects. Values in parentheses are clustered robust standard errors, at country level.

${ }^{*} p<0.10,{ }^{* *} p<0.05$, and ${ }^{* * *} p<0.01$.

Source: Authors' estimates 
Table 3: Sectoral Flows Covariates - Advanced Economies

\begin{tabular}{|c|c|c|c|c|c|c|c|c|c|c|}
\hline & \multicolumn{5}{|c|}{ Non-Resident Flows } & \multicolumn{5}{|c|}{ Resident Flows } \\
\hline & (1) & (2) & (3) & (4) & (5) & (6) & (7) & (8) & (9) & (10) \\
\hline & $\mathbf{C B}$ & GG & BK & NFC & OFC & $\mathbf{C B}$ & GG & BK & NFC & OFC \\
\hline \multirow[t]{2}{*}{ Global GDP Growth } & 0.153 & 0.214 & $1.599 * * *$ & $0.773 * * *$ & $0.419 * * *$ & $\begin{array}{l}-0.195 \\
\end{array}$ & 0.177 & $1.357 * * *$ & $0.920 * * *$ & 0.087 \\
\hline & $(0.299)$ & $(0.162)$ & $(0.529)$ & $(0.172)$ & $(0.129)$ & $(0.201)$ & $(0.157)$ & $(0.384)$ & $(0.233)$ & $(0.182)$ \\
\hline \multirow[t]{2}{*}{ Global Liquidity } & 0.001 & $0.034 *$ & $0.378 * * *$ & $0.082^{* *}$ & $0.043^{* *}$ & -0.006 & 0.005 & $0.233^{* * *}$ & $0.126^{* *}$ & $0.079 * * *$ \\
\hline & $(0.020)$ & $(0.018)$ & $(0.077)$ & $(0.030)$ & $(0.018)$ & $(0.022)$ & $(0.009)$ & $(0.045)$ & $(0.057)$ & $(0.026)$ \\
\hline \multirow[t]{2}{*}{ VIX } & -0.015 & $0.085^{* *}$ & $-0.128^{*}$ & 0.043 & 0.004 & -0.037 & 0.019 & -0.090 & 0.050 & $-0.084 * * *$ \\
\hline & $(0.066)$ & $(0.031)$ & $(0.075)$ & $(0.041)$ & $(0.018)$ & $(0.048)$ & $(0.014)$ & $(0.063)$ & $(0.045)$ & $(0.023)$ \\
\hline \multirow[t]{2}{*}{ Global Commodity Price } & 0.004 & $0.011^{*}$ & $-0.062 * * *$ & $-0.011 *$ & $-0.013 * * *$ & -0.001 & -0.001 & $-0.041 * *$ & -0.005 & $-0.027 * * *$ \\
\hline & $(0.005)$ & $(0.005)$ & $(0.016)$ & $(0.005)$ & $(0.005)$ & $(0.008)$ & $(0.003)$ & $(0.016)$ & $(0.005)$ & $(0.006)$ \\
\hline \multirow[t]{2}{*}{ Domestic GDP Growth } & 0.138 & $-0.198 * * *$ & $0.518 * * *$ & $0.213 * * *$ & $0.095 * * *$ & -0.007 & -0.001 & 0.126 & $0.157^{* *}$ & $-0.062 * *$ \\
\hline & $(0.088)$ & $(0.059)$ & & $(0.066)$ & & $(0.065)$ & $(0.040)$ & & $(0.073)$ & $(0.029)$ \\
\hline Obser & 453 & 525 & 525 & 525 & 525 & 525 & 503 & 525 & 525 & 525 \\
\hline R-squared & 0.058 & 0.252 & 0.410 & 0.313 & 0.272 & 0.118 & 0.588 & 0.234 & 0.485 & 0.378 \\
\hline Country F.E. & Yes & Yes & Yes & Yes & Yes & Yes & Yes & Yes & Yes & Yes \\
\hline
\end{tabular}

Notes: CB = central bank; GG = general government; BK = banks; NFC = non-financial corporates; and OFC = other financial corporate. Dependent variables are sectoral flows in percent of nominal GDP for non-resident (column 1-5) and resident (column 6-10) sectoral flows. Refer to Appendix 2 for the list of advanced economies. Regressors are in contemporaneous values, except for domestic GDP growth which was lagged. All specifications include country fixed effects. Values in parentheses are clustered robust standard errors, at country level. ${ }^{*} p<0.10,{ }^{* *} p<0.05$, and ${ }^{* * *} p<0.01$

Source: Authors' estimates. 
Table 4: Sectoral Flows Covariates - Emerging Economies

\begin{tabular}{|c|c|c|c|c|c|c|c|c|c|c|}
\hline & \multicolumn{5}{|c|}{ Non-Resident Flows } & \multicolumn{5}{|c|}{ Resident Flows } \\
\hline & (1) & (2) & (3) & (4) & (5) & (6) & (7) & (8) & (9) & (10) \\
\hline & CB & GG & BK & NFC & OFC & CB & GG & BK & NFC & OFC \\
\hline Global GDP Growth & $\begin{array}{l}-0.130^{* *} \\
(0.049)\end{array}$ & $\begin{array}{l}-0.068 \\
(0.098)\end{array}$ & $\begin{array}{l}0.399 * * * \\
(0.109)\end{array}$ & $\begin{array}{l}0.500 * * * \\
(0.177)\end{array}$ & $\begin{array}{l}0.027 \\
(0.044)\end{array}$ & $\begin{array}{l}0.163 \\
(0.209)\end{array}$ & $\begin{array}{l}0.064 \\
(0.095)\end{array}$ & $\begin{array}{l}0.155 \\
(0.159)\end{array}$ & $\begin{array}{l}0.082 \\
(0.201)\end{array}$ & $\begin{array}{l}-0.187^{* *} \\
(0.067)\end{array}$ \\
\hline Global Liquidity & $\begin{array}{l}0.007 \\
(0.010)\end{array}$ & $\begin{array}{l}-0.012 \\
(0.021)\end{array}$ & $\begin{array}{l}0.075^{* *} \\
(0.030)\end{array}$ & $\begin{array}{l}0.123 * * * \\
(0.039)\end{array}$ & $\begin{array}{l}0.027^{*} \\
(0.014)\end{array}$ & $\begin{array}{l}0.125 * * * \\
(0.036)\end{array}$ & $\begin{array}{l}0.008 \\
(0.015)\end{array}$ & $\begin{array}{l}0.047 \\
(0.050)\end{array}$ & $\begin{array}{l}0.140^{*} \\
(0.076)\end{array}$ & $\begin{array}{l}0.056 * * \\
(0.024)\end{array}$ \\
\hline VIX & $\begin{array}{l}0.009 \\
(0.007)\end{array}$ & $\begin{array}{l}0.035^{*} \\
(0.020)\end{array}$ & $\begin{array}{l}-0.006 \\
(0.027)\end{array}$ & $\begin{array}{l}0.043 \\
(0.044)\end{array}$ & $\begin{array}{l}-0.006 \\
(0.010)\end{array}$ & $\begin{array}{l}-0.011 \\
(0.033)\end{array}$ & $\begin{array}{l}-0.006 \\
(0.012)\end{array}$ & $\begin{array}{l}-0.022 \\
(0.034)\end{array}$ & $\begin{array}{l}-0.012 \\
(0.046)\end{array}$ & $\begin{array}{l}-0.012 \\
(0.020)\end{array}$ \\
\hline Global Commodity Price & $\begin{array}{l}0.001 \\
(0.001)\end{array}$ & $\begin{array}{l}0.008 * * * \\
(0.003)\end{array}$ & $\begin{array}{l}-0.000 \\
(0.005)\end{array}$ & $\begin{array}{l}0.012 \\
(0.009)\end{array}$ & $\begin{array}{l}0.000 \\
(0.002)\end{array}$ & $\begin{array}{l}-0.015^{*} \\
(0.008)\end{array}$ & $\begin{array}{l}0.001 * \\
(0.001)\end{array}$ & $\begin{array}{l}-0.004 \\
(0.004)\end{array}$ & $\begin{array}{l}0.002 \\
(0.006)\end{array}$ & $\begin{array}{l}-0.001 \\
(0.003)\end{array}$ \\
\hline Domestic GDP Growth & $\begin{array}{l}-0.025 \\
(0.027)\end{array}$ & $\begin{array}{l}-0.110^{* * *} \\
(0.020)\end{array}$ & $\begin{array}{l}0.201 * * * \\
(0.057)\end{array}$ & $\begin{array}{l}0.227 * * * \\
(0.061) \\
\end{array}$ & $\begin{array}{l}0.021 \\
(0.014) \\
\end{array}$ & $\begin{array}{l}-0.037 \\
(0.055) \\
\end{array}$ & $\begin{array}{l}0.004 \\
(0.010)\end{array}$ & $\begin{array}{l}0.067^{*} \\
(0.036) \\
\end{array}$ & $\begin{array}{l}0.110 \\
(0.100)\end{array}$ & $\begin{array}{l}-0.048^{*} \\
(0.026)\end{array}$ \\
\hline Observations & 615 & 666 & 673 & 673 & 656 & 247 & 200 & 247 & 247 & 237 \\
\hline R-squared & 0.095 & 0.209 & 0.189 & 0.447 & 0.157 & 0.189 & 0.129 & 0.107 & 0.249 & 0.411 \\
\hline Country F.E. & Yes & Yes & Yes & Yes & Yes & Yes & Yes & Yes & Yes & Yes \\
\hline
\end{tabular}


Table 5: Sectoral Flows Covariates - Equity Flows

\begin{tabular}{|c|c|c|c|c|c|c|c|c|c|c|}
\hline & \multicolumn{5}{|c|}{ Non-Resident Flows } & \multicolumn{5}{|c|}{ Resident Flows } \\
\hline & (1) & (2) & (3) & (4) & (5) & (6) & (7) & (8) & (9) & (10) \\
\hline & CB & GG & BK & NFC & OFC & CB & GG & BK & NFC & OFC \\
\hline \multirow[t]{2}{*}{ Global GDP Growth } & ․ & "-0.008 & 0.053 & $0.440 * * *$ & $0.074 * *$ & 0.000 & "-0.079 & "067** & $376^{* *}$ & 025 \\
\hline & & $(0.008)$ & $(0.039)$ & $(0.136)$ & $(0.029)$ & $(0.008)$ & $(0.079)$ & & $(0.143)$ & $(0.052)$ \\
\hline \multirow[t]{2}{*}{ Global Liquidity } & $\ldots$ & -0.000 & $0.041^{*}$ & $0.071 * * *$ & 0.014 & -0.002 & 0.014 & $0.026^{*}$ & $0.093^{* *}$ & $0.030 * *$ \\
\hline & & $(0.001)$ & $(0.023)$ & $(0.023)$ & $(0.008)$ & $(0.001)$ & $(0.014)$ & $(0$. & $(0.043)$ & $(0.012)$ \\
\hline \multirow[t]{2}{*}{ VIX } & $\ldots$ & -0.000 & -0.010 & 0.046 & 0.009 & 0.000 & -0.004 & -0.002 & 0.015 & -0.014 \\
\hline & & $(0.002)$ & $(0.008)$ & $(0.032)$ & $(0.006)$ & $(0.002)$ & $(0.004)$ & 5) & 26) & $(0.010)$ \\
\hline \multirow[t]{2}{*}{ Global Commodity Price } & $\ldots$ & 0.000 & -0.000 & 0.002 & $-0.002 * *$ & 0.000 & 0.001 & -0.001 & 0.000 & $-0.005^{* *}$ \\
\hline & & $(0.000)$ & $(0.0$ & (0. & $(0.001)$ & $(0.000)$ & & & 3) & $(0$. \\
\hline \multirow[t]{2}{*}{ Domestic GDP Growth } & $\ldots$ & -0.001 & 0.012 & $0.173^{* * *}$ & 0.015 & 0.002 & -0.005 & $0.017^{*}$ & $0.077^{*}$ & -0.010 \\
\hline & & $(0.001)$ & $(0.011)$ & & $(0.010)$ & $(0.002)$ & & & & $(0.015)$ \\
\hline$\overline{\text { Obser }}$ & $\ldots$ & 189 & 1198 & 1198 & 1166 & 114 & 513 & 772 & 772 & 753 \\
\hline R-squi & $\ldots$ & 0.424 & 0.481 & 0.298 & 0.194 & 0.193 & 0.565 & 0.222 & 0.454 & 0.374 \\
\hline Country F.E. & $\ldots$ & Yes & Yes & Yes & Yes & Yes & Yes & Yes & Yes & Yes \\
\hline \multicolumn{11}{|c|}{$\begin{array}{l}\text { Notes: } \mathrm{CB}=\text { central bank; GG = general government; BK = banks; NFC = non-financial corporates; and OFC = other financial corporate. } \\
\text { Dependent variables are sectoral flows in percent of nominal GDP for non-resident (column 1-5) and resident (column } 6 \text {-10) sectoral flows. } \\
\text { Equity flows include direct investment and portfolio equity flows. Regressors are in contemporaneous values, except for domestic GDP growth } \\
\text { which was lagged. All specifications include country fixed effects. Values in parentheses are clustered robust standard errors, at country level. } \\
* p<0.10,{ }^{* *} p<0.05 \text {, and }{ }^{* * *} p<0.01 \text {. } \\
\text { source: Authors' estimates. }\end{array}$} \\
\hline
\end{tabular}


Table 6: Sectoral Flows Covariates - Debt Flows

\begin{tabular}{|c|c|c|c|c|c|c|c|c|c|c|}
\hline & \multicolumn{5}{|c|}{ Non-Resident Flows } & \multicolumn{5}{|c|}{ Resident Flows } \\
\hline & (1) & (2) & (3) & (4) & (5) & (6) & (7) & (8) & (9) & (10) \\
\hline & CB & GG & BK & NFC & OFC & CB & GG & BK & NFC & OFC \\
\hline \multirow[t]{2}{*}{ Global GDP Growth } & (063 & 0.044 & $301 * * *$ & 0.075 & $0.092 * * *$ & 098 & 0.296 & & (064*** & 0.083 \\
\hline & $(0.050)$ & $(0.090)$ & & $(0.046)$ & $(0.033)$ & $(0.139)$ & $(0.176)$ & & $(0.024)$ & $(0.073)$ \\
\hline \multirow[t]{2}{*}{ Global Liquidity } & 0.008 & 0.009 & $0.073 * * *$ & $0.028 * * *$ & $0.018^{* *}$ & 0.019 & -0.011 & $0.069 * * *$ & 0.007 & $0.029 * *$ \\
\hline & $(0.008)$ & $(0.014)$ & $(0$. & $(0.009)$ & $(0.008)$ & $(0.013)$ & $(0.009)$ & & $(0.005)$ & $(0.013)$ \\
\hline \multirow[t]{2}{*}{ VIX } & 0.006 & $0.057 * * *$ & 0.002 & -0.001 & -0.009 & .040 & $0.027 * * *$ & -0.012 & $0.007^{*}$ & $-0.046^{* * *}$ \\
\hline & 007) & $(0.017)$ & $(0.016)$ & $(0.010)$ & $(0$. & $(0.031)$ & $(0$. & & $(0$. & $(0.0$ \\
\hline \multirow[t]{2}{*}{ Global Commodity Price } & 0.002 & $0.010 * * *$ & $-0.007 * *$ & 0.001 & $-0.003 * *$ & $-0.009 * *$ & -0.001 & -0.0 & $-0.002 * * *$ & $-0.014^{* * * *}$ \\
\hline & & $(0$. & $(0$. & $(0$. & & $(0.004)$ & & & & $(0$. \\
\hline \multirow[t]{2}{*}{ Domestic GDP Growth } & $-0.037 *$ & $-0.143^{* * *}$ & $0.090 * * *$ & $0.076^{* * * *}$ & $0.059 * * *$ & -0.039 & 0.029 & 0.031 & 0.013 & -0.014 \\
\hline & $(0.021)$ & $(0.029)$ & & $(0.023)$ & $(0.014)$ & $(0.037)$ & & & & $(0.016)$ \\
\hline be & 708 & 1191 & 1129 & 1162 & 1058 & 311 & 607 & 742 & 715 & 696 \\
\hline R-squ & 0.057 & 0.234 & 0.320 & 0.198 & 0.230 & 0.274 & 0.209 & 0.181 & 0.150 & 0.296 \\
\hline Country F.E. & Yes & Yes & Yes & Yes & Yes & Yes & Yes & Yes & Yes & Yes \\
\hline \multicolumn{11}{|c|}{$\begin{array}{l}\text { Notes: CB = central bank; GG = general government; BK = banks; NFC = non-financial corporates; and OFC = other financial corporate } \\
\text { Dependent variables are sectoral flows in percent of nominal GDP for non-resident (column 1-5) and resident (column 6-10) sectoral flow } \\
\text { Debt flows include portfolio debt and loans. Regressors are in contemporaneous values, except for domestic GDP growth which was laggec } \\
\text { All specifications include country fixed effects. Values in parentheses are clustered robust standard errors, at country level. }{ }^{*} p<0.10,{ }^{* *} p<0.0 \\
\text { and }{ }^{* * *} p<0.01 \text {. }\end{array}$} \\
\hline
\end{tabular}


Table 7: Co-movement Between Resident and Non-Resident Sectoral Flows (Conditional on Baseline Covariates and Country Fixed Effects)

\begin{tabular}{|c|c|c|c|c|c|}
\hline & \multicolumn{5}{|c|}{ Non-Resident Flows } \\
\hline & $\mathbf{C B}$ & GG & BK & NFC & $\mathrm{OFC}$ \\
\hline Resident Flows - CB & $0.195 * * *$ & $0.066^{*}$ & $0.551 * * *$ & $0.102 * *$ & $0.044 * *$ \\
\hline Resident Flows - GG & -0.039 & $0.738 * * *$ & -0.056 & $0.109^{*}$ & -0.041 \\
\hline Resident Flows - BK & 0.044 & 0.036 & $0.801 * * *$ & 0.018 & 0.042 \\
\hline Resident Flows - NFC & 0.084 & -0.044 & 0.355 & $0.459 * * *$ & $0.152 * * *$ \\
\hline Resident Flows - OFC & $-0.135^{*}$ & 0.097 & $0.414 * * *$ & $0.119 * * *$ & $0.353 * * *$ \\
\hline Observations & 623 & 700 & 700 & 700 & 700 \\
\hline R-squared & 0.153 & 0.398 & 0.802 & 0.605 & 0.575 \\
\hline \multirow[t]{3}{*}{ Country F.E. \& Controls } & Yes & Yes & Yes & Yes & Yes \\
\hline & \multicolumn{5}{|c|}{ Resident Flows } \\
\hline & $\mathbf{C B}$ & GG & BK & NFC & $\mathrm{OFC}$ \\
\hline Non-Resident Flows - CB & 0.154 & 0.032 & $0.439 * * *$ & $0.295^{* * *}$ & 0.029 \\
\hline Non-Resident Flows - GG & 0.093 & $0.297 * *$ & $0.315^{* *}$ & 0.051 & $0.111 * *$ \\
\hline Non-Resident Flows - BK & 0.066 & -0.003 & $0.601 * * *$ & $0.204^{*}$ & $0.076^{* * *}$ \\
\hline Non-Resident Flows - NFC & 0.045 & 0.037 & 0.026 & $0.568 * * *$ & $0.083 * *$ \\
\hline Non-Resident Flows - OFC & -0.081 & -0.055 & 0.080 & $0.659 * * *$ & $0.274 * * *$ \\
\hline Observations & 671 & 623 & 671 & 671 & 671 \\
\hline R-squared & 0.155 & 0.677 & 0.630 & 0.763 & 0.616 \\
\hline Country F.E. \& Controls & Yes & Yes & Yes & Yes & Yes \\
\hline \multicolumn{6}{|c|}{$\begin{array}{l}\text { Notes: } C B=\text { central bank; } G G=\text { general government; } B K=\text { banks; NFC = non-financial corporates; and } \\
\text { OFC = other financial corporate. Values refer to estimated coefficients of the regression resident (non- } \\
\text { resident) sectoral flows on global and domestic covariates and non-resident (resident) sectoral flows } \\
\text { (in rows). All specifications are regressed with country fixed effects and clustered robust standard errors } \\
\text { at the country level. }{ }^{*} p<0.10,{ }^{* *} p<0.05 \text {, and }{ }^{* * *} p<0.01 \text {. } \\
\text { Source: Authors' estimates }\end{array}$} \\
\hline
\end{tabular}

Table 8: Number of Capital Control Adjustments, by Sector and Instrument

\begin{tabular}{|c|c|c|c|c|c|c|}
\hline & \multicolumn{2}{|c|}{ BK } & \multicolumn{2}{|c|}{ NFC } & \multicolumn{2}{|c|}{ OFC } \\
\hline & $\begin{array}{c}\text { Non- } \\
\text { Resident }\end{array}$ & Resident & $\begin{array}{c}\text { Non- } \\
\text { Resident }\end{array}$ & Resident & $\begin{array}{c}\text { Non- } \\
\text { Resident }\end{array}$ & Resident \\
\hline & Flows & Flows & Flows & Flows & Flows & Flows \\
\hline Direct investment & 42 & 44 & 47 & 56 & 38 & 44 \\
\hline Portfolio equity & 38 & 47 & 38 & 66 & 36 & 101 \\
\hline Portfolio debt & 58 & 51 & 46 & 64 & 40 & 113 \\
\hline Collective investment & 26 & 42 & 25 & 54 & 26 & 102 \\
\hline Credit & 75 & 54 & 71 & 18 & 50 & 41 \\
\hline
\end{tabular}

Notes: $\mathrm{BK}=$ banking sector, NFC $=$ non-financial corporates, OFC $=$ other financial corporates. Values refer to the total number of sectoral controls for both non-resident and resident sectoral flows across different types of investments.

Source: Authors' classification and computations based on Lepers and Mehigan (2019). 
Table 9: Non-Resident Sectoral Flows on Non-Resident Sectoral Controls (Summary of Estimates) ALL COUNTRIES

\begin{tabular}{|c|c|c|c|c|c|c|c|c|c|}
\hline \multicolumn{10}{|c|}{ ALL COUNTRIES } \\
\hline \multirow[b]{2}{*}{ Non-Resident Flows } & \multicolumn{3}{|c|}{ Pooled OLS } & \multicolumn{3}{|c|}{ Two-Step, no FE } & \multicolumn{3}{|c|}{ Fixed Effects } \\
\hline & BK & NFC & OFC & BK & NFC & OFC & BK & NFC & OFC \\
\hline \multirow[t]{2}{*}{ Corresp. Sectoral Controls (Tightening) } & $-0.351 *$ & -0.115 & $-0.149 * * *$ & -0.194 & -0.004 & $-0.091 *$ & -0.004 & 0.106 & -0.036 \\
\hline & $(0.191)$ & $(0.111)$ & $(0.051)$ & $(0.186)$ & $(0.098)$ & $(0.047)$ & $(0.183)$ & $(0.094)$ & $(0.045)$ \\
\hline R-squared & 0.138 & 0.145 & 0.074 & 0.144 & 0.152 & 0.076 & 0.349 & 0.360 & 0.231 \\
\hline \multirow[t]{2}{*}{ Corresp. Sectoral Controls (All) } & -0.028 & -0.025 & 0.014 & -0.078 & 0.006 & 0.010 & $-0.147 *$ & $-0.118 *$ & $-0.036 *$ \\
\hline & $(0.087)$ & $(0.064)$ & $(0.022)$ & $(0.094)$ & $(0.061)$ & $(0.023)$ & $(0.089)$ & $(0.063)$ & $(0.021)$ \\
\hline R-squared & 0.136 & 0.144 & 0.073 & 0.144 & 0.152 & 0.075 & 0.350 & 0.362 & 0.232 \\
\hline Global and domestic factors & & $\mathrm{Y}$ & & & $\mathrm{Y}$ & & & $\mathrm{Y}$ & \\
\hline Observations & & 907 & & & 853 & & & 907 & \\
\hline
\end{tabular}

\begin{tabular}{|c|c|c|c|c|c|c|c|c|c|}
\hline \multicolumn{10}{|c|}{ EMERGING ECONOMIES } \\
\hline \multirow[b]{2}{*}{ Non-Resident Flows } & \multicolumn{3}{|c|}{ Pooled OLS } & \multicolumn{3}{|c|}{ Two-Step, no FE } & \multicolumn{3}{|c|}{ Fixed Effects } \\
\hline & BK & NFC & OFC & BK & NFC & OFC & $\mathbf{B K}$ & NFC & OFC \\
\hline Corresp. Sectoral Controls (Tightening) & $\begin{array}{c}\mathbf{- 0 . 1 4 0 *} \\
(0.080) \\
\end{array}$ & $\begin{array}{c}-\mathbf{- 0 . 2 4 9} * \\
(0.146) \\
\end{array}$ & $\begin{array}{c}-\mathbf{- 0 . 0 7 6}^{*} \\
(0.040)\end{array}$ & $\begin{array}{c}-\mathbf{- 0 . 1 4 4} * \\
(0.078) \\
\end{array}$ & $\begin{array}{l}-0.044 \\
(0.132)\end{array}$ & $\begin{array}{c}-\mathbf{- 0 . 0 7 0} * \\
(0.039) \\
\end{array}$ & $\begin{array}{l}-0.046 \\
(0.081)\end{array}$ & $\begin{array}{c}0.096 \\
(0.137) \\
\end{array}$ & $\begin{array}{l}-0.052 \\
(0.039)\end{array}$ \\
\hline R-squared & 0.093 & 0.173 & 0.060 & 0.102 & 0.156 & 0.061 & 0.171 & 0.402 & 0.177 \\
\hline Corresp. Sectoral Controls (All) & $\begin{array}{c}\mathbf{- 0 . 0 8 2} * * \\
(0.040) \\
\end{array}$ & $\begin{array}{c}0.029 \\
(0.061) \\
\end{array}$ & $\begin{array}{l}-0.030 \\
(0.021) \\
\end{array}$ & $\begin{array}{c}\mathbf{- 0 . 0 8 6} * * \\
(0.041) \\
\end{array}$ & $\begin{array}{c}0.070 \\
(0.058) \\
\end{array}$ & $\begin{array}{l}-0.026 \\
(0.030) \\
\end{array}$ & $\begin{array}{c}\mathbf{- 0 . 0 9 7} * * \\
(0.043) \\
\end{array}$ & $\begin{array}{l}-0.081 \\
(0.063) \\
\end{array}$ & $\begin{array}{l}-0.026 \\
(0.020) \\
\end{array}$ \\
\hline R-squared & 0.093 & 0.171 & 0.059 & 0.102 & 0.158 & 0.061 & 0.173 & 0.403 & 0.177 \\
\hline Global and domestic factors & & $\mathrm{Y}$ & & & $\bar{Y}$ & & & $\mathrm{Y}$ & \\
\hline Observations & & 408 & & & 384 & & & 408 & \\
\hline
\end{tabular}

Notes: BK = banks; NFC = non-financial corporates; and OFC = other financial corporates. Values refer to estimated coefficients of the regression sectoral flows on global (contemporaneous) and domestic (lagged) baseline regressors and corresponding sectoral controls. Values in parentheses are clustered robust standard errors, at country level. ${ }^{*} p<0.10,{ }^{* *}$ $\mathrm{p}<0.05$, and $* * * \mathrm{p}<0.01$. 
Appendix 1: Sectoral Flows Data Summary

\begin{tabular}{|c|c|c|c|c|c|c|c|}
\hline Types of Investments & Sector & $\begin{array}{c}\text { Reported } \\
\text { Zeros }\end{array}$ & $\begin{array}{c}\text { Reported } \\
\text { Values }\end{array}$ & $\begin{array}{c}\text { Total } \\
\text { Reported }\end{array}$ & Computed & Filled-In & $\begin{array}{c}\text { Total } \\
\text { Computed }\end{array}$ \\
\hline Direct Investment Abroad & BK & 0 & 0 & $\mathbf{0}$ & 772 & 0 & 772 \\
\hline Direct Investment Abroad & NFC & 0 & 0 & 0 & 772 & 0 & 772 \\
\hline Direct Investment Abroad & $\mathrm{OFC}$ & 19 & 0 & 19 & 753 & 0 & 753 \\
\hline Foreign Direct Investment & BK & 0 & 0 & 0 & 1198 & 0 & 1198 \\
\hline Foreign Direct Investment & $\mathrm{NFC}$ & 0 & 0 & 0 & 1198 & 0 & 1198 \\
\hline Foreign Direct Investment & $\mathrm{OFC}$ & 47 & 0 & 47 & 1151 & 0 & 1151 \\
\hline Portfolio Equity Assets & $\mathrm{CB}$ & 380 & 75 & 455 & 39 & 0 & 39 \\
\hline Portfolio Equity Assets & GG & 216 & 324 & 540 & 39 & 11 & 50 \\
\hline Portfolio Equity Assets & BK & 66 & 522 & 588 & 102 & 0 & 102 \\
\hline Portfolio Equity Assets & NFC & 8 & 357 & 365 & 199 & 124 & 323 \\
\hline Portfolio Equity Assets & $\mathrm{OFC}$ & 20 & 349 & 369 & 286 & 31 & 317 \\
\hline Portfolio Debt Assets & $\mathrm{CB}$ & 285 & 201 & 486 & 36 & 0 & 36 \\
\hline Portfolio Debt Assets & GG & 164 & 406 & 570 & 54 & 0 & 54 \\
\hline Portfolio Debt Assets & BK & 3 & 616 & 619 & 86 & 0 & 86 \\
\hline Portfolio Debt Assets & NFC & 14 & 357 & 371 & 223 & 128 & 351 \\
\hline Portfolio Debt Assets & OFC & 31 & 322 & 353 & 313 & 27 & 340 \\
\hline Portfolio Equity Liabilities & $\mathrm{CB}$ & 427 & 9 & 436 & 0 & 0 & 0 \\
\hline Portfolio Equity Liabilities & GG & 423 & 23 & 446 & 10 & 1 & 11 \\
\hline Portfolio Equity Liabilities & BK & 114 & 710 & 824 & 124 & 0 & 124 \\
\hline Portfolio Equity Liabilities & NFC & 48 & 506 & 554 & 267 & 260 & 527 \\
\hline Portfolio Equity Liabilities & $\mathrm{OFC}$ & 124 & 414 & 538 & 413 & 87 & 500 \\
\hline Portfolio Debt Liabilities & $\mathrm{CB}$ & 599 & 184 & 783 & 22 & 0 & 22 \\
\hline Portfolio Debt Liabilities & GG & 62 & 1010 & 1072 & 73 & 0 & 73 \\
\hline Portfolio Debt Liabilities & BK & 112 & 823 & 935 & 97 & 1 & 98 \\
\hline Portfolio Debt Liabilities & NFC & 79 & 509 & 588 & 197 & 246 & 443 \\
\hline Portfolio Debt Liabilities & OFC & 150 & 397 & 547 & 376 & 9 & 385 \\
\hline OI Assets Equity & GG & 127 & 316 & 443 & 0 & 0 & 0 \\
\hline OI Assets Currency and Deposits & $\mathrm{CB}$ & 191 & 362 & 553 & 0 & 0 & 0 \\
\hline OI Assets Currency and Deposits & GG & 180 & 385 & 565 & 3 & 0 & 3 \\
\hline OI Assets Currency and Deposits & BK & 25 & 691 & 716 & 30 & 0 & 30 \\
\hline OI Assets Currency and Deposits & $\mathrm{NFC}$ & 6 & 412 & 418 & 0 & 310 & 310 \\
\hline OI Assets Currency and Deposits & OFC & 41 & 307 & 348 & 276 & 19 & 295 \\
\hline OI Assets Loans & $\mathrm{CB}$ & 379 & 131 & 510 & 3 & 0 & 3 \\
\hline OI Assets Loans & GG & 194 & 453 & 647 & 6 & 6 & 12 \\
\hline OI Assets Loans & BK & 8 & 691 & 699 & 40 & 2 & 42 \\
\hline OI Assets Loans & NFC & 28 & 352 & 380 & 0 & 260 & 260 \\
\hline OI Assets Loans & $\mathrm{OFC}$ & 74 & 287 & 361 & 243 & 40 & 283 \\
\hline OI Assets Insurance and Pensions & $\mathrm{CB}$ & 265 & 0 & 265 & 0 & 0 & 0 \\
\hline OI Assets Insurance and Pensions & GG & 270 & 9 & 279 & 0 & 0 & 0 \\
\hline OI Assets Insurance and Pensions & BK & 255 & 12 & 267 & 0 & 1 & 1 \\
\hline OI Assets Insurance and Pensions & NFC & 166 & 131 & 297 & 0 & 21 & 21 \\
\hline OI Assets Insurance and Pensions & OFC & 87 & 233 & 320 & 21 & 22 & 43 \\
\hline OI Assets Trade Credits and Advances & $\mathrm{CB}$ & 280 & 24 & 304 & 0 & 0 & 0 \\
\hline OI Assets Trade Credits and Advances & GG & 254 & 242 & 496 & 1 & 0 & 1 \\
\hline OI Assets Trade Credits and Advances & BK & 251 & 96 & 347 & 0 & 0 & 0 \\
\hline OI Assets Trade Credits and Advances & $\mathrm{NFC}$ & 8 & 368 & 376 & 19 & 305 & 324 \\
\hline OI Assets Trade Credits and Advances & $\mathrm{OFC}$ & 133 & 156 & 289 & 93 & 1 & 94 \\
\hline OI Assets Others & $\mathrm{CB}$ & 309 & 173 & 482 & 8 & 0 & 8 \\
\hline OI Assets Others & GG & 201 & 387 & 588 & 30 & 0 & 30 \\
\hline OI Assets Others & BK & 127 & 427 & 554 & 60 & 1 & 61 \\
\hline OI Assets Others & NFC & 102 & 260 & 362 & 0 & 259 & 259 \\
\hline OI Assets Others & OFC & 74 & 231 & 305 & 227 & 21 & 248 \\
\hline OI Reserve Assets & $\mathrm{CB}$ & 0 & 772 & 772 & 0 & 0 & 0 \\
\hline OI Liabilities Equity & GG & 339 & 175 & 514 & 0 & 0 & 0 \\
\hline OI Liabilities Currency and Deposits & CB & 198 & 716 & 914 & 3 & 22 & 25 \\
\hline OI Liabilities Currency and Deposits & GG & 497 & 184 & 681 & 17 & 0 & 17 \\
\hline OI Liabilities Currency and Deposits & BK & 28 & 1074 & 1102 & 44 & 0 & 44 \\
\hline OI Liabilities Currency and Deposits & $\mathrm{NFC}$ & 380 & 54 & 434 & 0 & 146 & 146 \\
\hline OI Liabilities Currency and Deposits & OFC & 367 & 92 & 459 & 139 & 22 & 161 \\
\hline OI Liabilities Loans & $\mathrm{CB}$ & 336 & 605 & 941 & 3 & 0 & 3 \\
\hline OI Liabilities Loans & GG & 49 & 1084 & 1133 & 22 & 10 & 32 \\
\hline OI Liabilities Loans & BK & 202 & 773 & 975 & 39 & 28 & 67 \\
\hline OI Liabilities Loans & $\mathrm{NFC}$ & 0 & 615 & 615 & 0 & 533 & 533 \\
\hline OI Liabilities Loans & $\mathrm{OFC}$ & 72 & 493 & 565 & 478 & 43 & 521 \\
\hline OI Liabilities Insurance and Pensions & $\mathrm{CB}$ & 380 & 0 & 380 & 0 & 0 & 0 \\
\hline OI Liabilities Insurance and Pensions & GG & 418 & 0 & 418 & 0 & 0 & 0 \\
\hline OI Liabilities Insurance and Pensions & BK & 368 & 0 & 368 & 0 & 0 & 0 \\
\hline OI Liabilities Insurance and Pensions & $\mathrm{NFC}$ & 364 & 20 & 384 & 0 & 8 & 8 \\
\hline OI Liabilities Insurance and Pensions & $\mathrm{OFC}$ & 175 & 307 & 482 & 8 & 58 & 66 \\
\hline OI Liabilities Trade Credits and Advances & $\mathrm{CB}$ & 416 & 39 & 455 & 0 & 0 & 0 \\
\hline OI Liabilities Trade Credits and Advances & GG & 478 & 225 & 703 & 3 & 0 & 3 \\
\hline OI Liabilities Trade Credits and Advances & BK & 368 & 114 & 482 & 1 & 0 & 1 \\
\hline OI Liabilities Trade Credits and Advances & NFC & 28 & 598 & 626 & 128 & 318 & 446 \\
\hline OI Liabilities Trade Credits and Advances & OFC & 233 & 238 & 471 & 142 & 0 & 142 \\
\hline OI Liabilities Others & $\mathrm{CB}$ & 459 & 271 & 730 & 8 & 0 & 8 \\
\hline OI Liabilities Others & GG & 428 & 425 & 853 & 41 & 5 & 46 \\
\hline OI Liabilities Others & BK & 191 & 719 & 910 & 67 & 1 & 68 \\
\hline OI Liabilities Others & $\mathrm{NFC}$ & 201 & 342 & 543 & 1 & 361 & 362 \\
\hline OI Liabilities Others & $\mathrm{OFC}$ & 177 & 316 & 493 & 337 & 37 & 374 \\
\hline Total & & 14,578 & 25,501 & 40,079 & 11,341 & 3,785 & 15,126 \\
\hline Share & & & & 72.6 & 20.5 & 6.9 & \\
\hline
\end{tabular}




\section{Appendix 2: Country Classification}

\begin{tabular}{|c|c|}
\hline Advanced Economies & Emerging Economies \\
\hline Australia & "Albania ${ }^{\wedge *}$ \\
\hline Austria & Argentina $^{\wedge}$ \\
\hline Belgium & Armenia $^{\wedge *}$ \\
\hline Canada & Belarus* \\
\hline Czech Republic & Bosnia and Herzegovina ${ }^{\wedge *}$ \\
\hline Denmark & 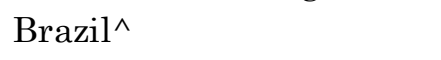 \\
\hline Estonia & Bulgaria \\
\hline Finland & Chile \\
\hline France & China $^{\wedge}$ \\
\hline Germany & Colombia \\
\hline Greece & Croatia \\
\hline Israel & Georgia $^{\wedge *}$ \\
\hline Italy & Hungary \\
\hline Japan & India \\
\hline Korea & Indonesia^ $^{\wedge}$ \\
\hline Latvia & Kazakhstan $^{\wedge *}$ \\
\hline Lithuania & $\operatorname{Kosovo}^{\wedge *}$ \\
\hline Netherlands & Malaysia \\
\hline New Zealand & $\operatorname{Mexico}^{\wedge}$ \\
\hline Norway & Mongolia $^{\wedge *}$ \\
\hline Portugal & Morocco* \\
\hline Slovakia & North Macedonia $^{\wedge *}$ \\
\hline Slovenia & Pakistan $^{\wedge *}$ \\
\hline Spain & Paraguay $^{\wedge *}$ \\
\hline Sweden & Peru$^{\wedge}$ \\
\hline Switzerland & Philippines $^{\wedge}$ \\
\hline United Kingdom & Poland \\
\hline \multirow[t]{9}{*}{ United States } & Romania $^{\wedge}$ \\
\hline & Russia $^{\wedge}$ \\
\hline & Serbia $^{\wedge}$ \\
\hline & South Africa^ \\
\hline & Thailand \\
\hline & Turkey \\
\hline & Ukraine \\
\hline & Uruguay^$^{\wedge}$ \\
\hline & Zambia $^{\wedge *}$ \\
\hline
\end{tabular}

Notes: $(\wedge)$ indicates emerging economies without resident sectoral flows data. $\left({ }^{*}\right)$ indicates emerging economies without available data for sectoral controls. 
Appendix 3: Data Definitions and Sources

\begin{tabular}{|c|c|c|}
\hline Data & Notes & Sources \\
\hline Sectoral capital flows & $\begin{array}{l}\text { Refer to Section } 2.1 \text { for } \\
\text { detailed discussions on data } \\
\text { computations and sources }\end{array}$ & $\begin{array}{l}\text { Authors' calculations based } \\
\text { on IMF Balance of Payment } \\
\text { Statistics, IMF Coordinated } \\
\text { Portfolio Investment Survey, } \\
\text { IMF International Investment } \\
\text { Position, BIS Locational } \\
\text { Banking Statistics, OECD } \\
\text { Direct Investment Dataset, } \\
\text { IMF FSSA reports, and } \\
\text { national sources accessed } \\
\text { through CEIC database }\end{array}$ \\
\hline Nominal GDP & US dollar billions & $\begin{array}{l}\text { IMF World Economic } \\
\text { Outlook Database } 2019\end{array}$ \\
\hline Global GDP growth & $\begin{array}{l}\text { Year-on-year change in } \\
\text { percent of global real GDP }\end{array}$ & $\begin{array}{l}\text { IMF World Economic } \\
\text { Outlook Database } 2019\end{array}$ \\
\hline Global liquidity & $\begin{array}{l}\text { Index measuring the ease of } \\
\text { financing (credit) in global } \\
\text { financial markets }\end{array}$ & $\begin{array}{l}\text { Bank for International } \\
\text { Settlements }\end{array}$ \\
\hline VIX & $\begin{array}{l}\text { Index measuring } 30 \text {-day } \\
\text { expected volatility of the } \\
\text { U.S. stock market, derived } \\
\text { from real-time, mid-quote } \\
\text { prices of S\&P } 500 B \text { Index } \\
\text { (SPXSM) call, and put } \\
\text { options }\end{array}$ & Chicago Board of Exchange \\
\hline Global Commodity Price & $\begin{array}{l}\text { Index pertaining to IMF's } \\
\text { Primary Commodity Prices }\end{array}$ & International Monetary Fund \\
\hline Domestic GDP Growth & $\begin{array}{l}\text { Year-on-year change of real } \\
\text { GDP }\end{array}$ & $\begin{array}{l}\text { IMF World Economic } \\
\text { Outlook Database } 2019\end{array}$ \\
\hline Governance & $\begin{array}{l}\text { Average of individual } \\
\text { country percentile ranking } \\
\text { on measure pertaining to } \\
\text { voice and accountability; } \\
\text { political stability; } \\
\text { government effectiveness; } \\
\text { regulatory quality; rule of } \\
\text { law; and control of } \\
\text { corruption }\end{array}$ & $\begin{array}{l}\text { Worldwide Governance } \\
\text { Indicators }\end{array}$ \\
\hline Financial depth & $\begin{array}{l}\text { Domestic credit provided by } \\
\text { the financial sector in } \\
\text { percentage of nominal GDP }\end{array}$ & $\begin{array}{l}\text { World Bank's World } \\
\text { Development Indicators }\end{array}$ \\
\hline Financial Openness & $\begin{array}{l}\text { Standardised capital } \\
\text { account openness measure }\end{array}$ & Chinn and Ito (2006) \\
\hline Risk premia & $\begin{array}{l}\text { Difference between U.S. } \\
\text { long-term government bond } \\
\text { yields and Moody's Baa } \\
\text { corporate bond yields }\end{array}$ & $\begin{array}{l}\text { IMF International Financial } \\
\text { Statistics and national } \\
\text { source. }\end{array}$ \\
\hline Global Liquidity Growth & $\begin{array}{l}\text { Annual year-on-year } \\
\text { change of Global Liquidity } \\
\text { Index }\end{array}$ & Authors' calculations \\
\hline
\end{tabular}




\begin{tabular}{|l|l|l|}
\hline \multicolumn{1}{|c|}{ Data } & \multicolumn{1}{|c|}{ Notes } & \multicolumn{1}{c|}{ Sources } \\
\hline Sectoral capital controls & Refer to Section 5.2 for & Authors' calculation using \\
& detailed discussions on data & sector-specific capital \\
& computations and sources & controls based on Lepers \\
& & and Mehigan (2019), IMF \\
& & AREAER, and OECD data. \\
\hline
\end{tabular}




\section{Appendix 4: Coding Capital Controls Dataset}

\section{A4. 1 Coding Rules in the Lepers and Mehigan (2019) Dataset}

Removal or easing of a policy measure are coded as -1 and introduction or tightening of a measure as +1 , episodic changes are considered. This enables the analysis to get closer to the intensity of a measure rather than simply its presence or introduction or removal. The policy data is available at daily frequency. In the context of their work, data is aggregated at the yearly frequency. Within the same year, there can be several policy actions. In transforming the list of policy actions into an annual database, all tightening and easing actions taken in the same year are added up.

The following coding rules have been followed in the construction of the dataset:

- Restrictions are coded at their date of implementation, not announcement. While this prevents the analysis of the immediate reaction of economic actors to announcements, it allows a much more consistent timing of actions across countries and importantly increases the coverage. The IMF's AREAER notably provides only the date of implementation.

- Restrictions made to specific countries based on political or national security reasons are not included.

- Restrictions derived from bilateral free trade agreement or investment agreement that applies to specific countries are not included.

- Restrictions on FDI are coded regardless of whether they are sector specific or general restrictions.

- Restrictions on use of accounts are coded as restrictions to the targeted cross border capital operation, as it is the case under the OECD Capital Movements Code.

- Restrictions on FDI in real estate are not considered as FDI restrictions, since these pertain to a different category in the AREAER, and thus classified under the investment in real estate category.

- Requirements of repatriation of the income from a sale in foreign markets are considered controls.

- In the case of securities, restrictions on purchase locally by non-residents, and on sale or issue abroad by residents are coded as controls on capital inflows, as usual in the literature.

- Conversely, restrictions on the purchase abroad by residents, and sale or issue locally by non-residents are coded as controls on capital outflows, as usual in the literature.

- Requirements of "reporting", "registration" or "notification" are dropped as they pertain to formalities.

- Measures impacting several categories of operations are recorded several times as they will impact several capital movements.

- A measure that affects both the inflow and outflow dimension of a specific operation is coded twice, as inflow and outflow action.

- With regards to restrictions on derivatives, when there is no obvious way to tell whether the restrictions is impacting inflows or outflows (derivatives like FX swaps involve both inflow and outflow components), the restriction is coded twice as inflow and outflow action, as usual in the literature.

- Restrictions on foreign investment by resident institutional investors, including insurance companies and pension funds, are included as restrictions. 


\section{A4.2 Coding Rules for Sector-Specific Capital Controls}

- Sectors have been classified by resident sector, i.e., for controls on inflows, we code the invested/recipient sector. For outflow controls, we code the investing/source sector.

- Sectors are classified based on the manual reading of the description of the measure in the IMF's AREAER or any other sources coded by Lepers and Mehigan (2019).

- We classify measures according to whether they impact the BK, NFC, or OFC sector. We leave out the government and central bank sector as specific rules generally apply despite some of the controls impacting the public sector, i.e., regarding sovereign bonds. On the other hand, we treat operations involving state-owned enterprises as NFCs, OFCs or Banks depending on the nature of their operations.

- When several sectors are mentioned in the description, they are coded as controls impacting each of the sector mentioned. When all sectors are indiscriminately concerned by the measure, it is coded as impacting all sectors. For the empirical analysis, additional aggregation technics and variables are computed, recording BK-only, NFC-only, or OFC-only controls, i.e., measures that are sector-specific.

- To match our flow classification, when a measure applies to individuals, it is classified under NFCs.

- For securities, restrictions on the issuance are generally allowed for classifying the specific issuing sector, while for purchase and sale of securities, all sectors may be involved.

- When no specific sector is mentioned in the description, we make specific assumptions based on manual reading of the measure and likely impact:

- Farmland, agriculture, and commercial real estate such as hotels are classified as NFCs even though the financial sector is now a major real estate investor for speculative purposes or long-term investment.

- Residential real estate is classified also in NFCs as we assume it is mostly individuals who are buying and selling residential real estate. In practice, the financial sector may also be involved.

- If unspecified and unless it concerns relations with affiliates abroad, restrictions on outward financial credit and financial guarantees and sureties are classified under Banks, assuming NFCs traditionally do not engage in financial credit provision and lending by OFCs is relatively less significant.

- Restrictions on inward credit related to international commercial transactions/ import/exports are classified as NFCs.

- Matching our capital flow classification, when unspecified, we do not systematically classify inward and outward FDI restrictions as NFC restrictions, as FDI may be involving banks and OFCs. We add all categories in this case.

- When a transaction is simply intermediated by financial institutions on behalf of other sectors, the investing sector is coded, not by intermediary sector.

- Restrictions on financial derivatives were left out to match the breakdown of our capital flow dataset. 